\title{
Northeastern Atlantic benthic foraminifera during the last 45,000 years: Changes in productivity seen from the bottom up
}

\author{
E. Thomas, ${ }^{1,2}$ L. Booth, M. Maslin, ${ }^{3}$ and N. J. Shackleton \\ Godwin Laboratory, Subdepartment of Quatemary Research, University of Cambridge, Cambridge \\ England
}

Abstract. We studied benthic foraminifera from the last $45 \mathrm{kyr}$ in the $>63 \mu \mathrm{m}$ size fraction in Biogeochemical Ocean Flux Studies (BOFS) cores 5K (50'41.3' N, 21 $1^{\circ} 51.9^{\prime} \mathrm{W}$, depth $3547 \mathrm{~m}$ ) and $14 \mathrm{~K}\left(58^{\circ} 37.2 \mathrm{~N}, 1^{\circ} 26.2^{\prime} \mathrm{W}\right.$, depth $\left.1756 \mathrm{~m}\right)$, at a time resolution of several hundreds to a thousand years. The deepest site showed the largest fluctuations in faunal composition, species richness, and benthic foraminiferal accumulation rates; the fluctuations resulted from changes in abundance of Epistominella exigua and Alabaminella weddellensis. In the present oceans, these species bloom opportunistically when a spring plankton bloom results in seasonal deposition of phytodetritus on the seafloor. The "phytodetritus species" had very low relative abundances and accumulation rates during the last glacial maximum. A strong increase in absolute and relative abundance of $E$ exigua and $A$ weddellensis during deglaciation paralleled the decrease in abundance of the polar planktonic foraminifer Neogloboguadrina pachyderma (s), and the increase in abundance of warmer water planktonic species such as Globigerina bulloides. This strong increase in relative abundance of the "phytodetritus species" and the coeval increase in benthic foraminiferal accumulation rate were thus probably caused by an increase in the deposition of phytodetritus to the seafloor (and thus probably of surface productivity) when the polar front retreated to higher latitudes. The abundance of "phytodetritus species" decreased during the Younger Dryas, but not to the low levels of fully glacial conditions. During Heinrich events (periods of excessive melt-water formation and ice rafting) benthic accumulation rates were very low, as were the absolute and relative abundances of the "phytodetritus species", supporting suggestions that surface productivity was very low during these events. In both cores Pullenia and Cassidulina species were common during isotope stages 2,3 and 4, as were bolivinid, buliminid and uvigerinid species. High relative abundances of these species have been interpreted as indicative either of sluggish deep water circulation or of high organic carbon fluxes to the seafloor. In our cores, relative abundances of these species are negatively correlated with benthic foraminiferal accumulation rates, and we can thus not interpret them as indicative of increased productivity during glacials. The percentage of these "low oxygen" species calculated on a "phytodetritus species" - free basis decreased slightly at deglaciation at $5 \mathrm{~K}$, but not at $14 \mathrm{~K}$. This suggests that decreased production of North Atlantic Deep Water during the last glacial might have slightly affected benthic foraminiferal faunas in the eastern North Atlantic at $3547 \mathrm{~m}$ depth, but not at $1756 \mathrm{~m}$. In conclusion, major changes in deep-sea benthic foraminiferal faunas over the last 45,000 years in our cores from the northeastern Atlantic were the result of changes in surface water productivity, not of changes in deep water circulation; productivity was lower during the glacial, probably because of extensive ice cover.

\section{Introduction}

Deep-sea benthic foraminiferal faunas contain information on oceanic deep environments, which underwent significant change during the glacial-interglacial alternations of the last

\footnotetext{
${ }^{1}$ Now at Center for the Study of Global Change, Department of Geology and Geophysics, Yale University, New Haven, Connecticut.

${ }^{2}$ Also at Department of Earth and Environmental Sciences, Wesleyan University, Middletown, Connecticut.

${ }^{3}$ Now at Geologisch-Paliontologisch Inetitut und Museum der Universität Kiel, Kiel, Germany.
}

Copyright 1995 by the American Geophysical Union

Paper number 94PA03056.

0883-8305/95/94PA-03056\$10.00
2.5 million years, especially in the northern Atlantic. Abundant stable isotope and trace element evidence indicates that formation of North Atlantic Deep Water (NADW) during glacial maxima was reduced or absent, which contributed to the cooling of high-latitude regions [e.g., Ruddiman and McIntyre, 1985; Boyle, 1986, 1992; Broecker, 1986; Labeyrie et al., 1992; Curry et al., 1988; Duplessy et al., 1988; Broecker et al., 1989; Imbrie et al., 1992; Oppo and Lehman, 1993; Bertram et al., this issue] .

Formation of intermediate waters masses in the northern Atlantic, however, was more intensive during glacial maxima than at present [e.g., Boyle and Rosener, 1990; Herguera et al., 1992; Oppo and Lehman, 1993]. These changes in formation of deep and intermediate waters have been attributed to lowered salinities in the glacial northern Atlantic Ocean [e.g., Duplessy et al., 1988, 1993; Maslin, 1993; Maslin et 
$a l$, this issue]. Disturbances in surface water density in areas of deep water formation could switch the deep ocean circulation system from one mode of circulation to another [e.g., Broecker and Denton, 1989; Birchfield and Broecker, 1990; Broecker et al., 1990; Lehman and Keigwin, 1992]. Such a mechanism has been invoked to explain the retum to almost glacial conditions (including mode of deep water circulation) during the course of the last deglaciation, resulting in the cold Younger Dryas period [e.g., Broecker et al., 1988, 1989, 1990; Flower and Kennett, 1990; Kennett, 1990; Fairbanks et al, 1992], and similar cold periods during earlier glacial - interglacial transitions [e.g., Seidenkrantz, 1993].

Recently, short-term changes in ice sheet dynamics ("Heinrich events") were recognized in isotope stages 2, 3 and 4 [Heinrich, 1988; Andrews et al., 1992; Bond et al., 1992; Broecker et al., 1992; Manighetti et al., this issue; Maslin et al., this issue]. During these events iceberg transport and deposition of large amounts of ice-rafted material to the sea floor occurred mainly in an east-west belt $\left(40^{\circ}-55^{\circ} \mathrm{N}\right)$ across the Atlantic [Ruddiman, 1977; Bond et al, 1992; Grousset et al., 1993], and surface waters had exceptionally low temperatures and low salinities. The cause of Heinrich events and their possible effects on deep-water formation are still actively discussed [e.g., Bond et al, 1992; Andrews, 1992; Grousset et al., 1993; Maslin, 1993; Alley and MacAyeal, 1994; Maslin et al., this issue; Beveridge et al, this issue].

Major, rapid changes in deep water circulation would be expected to influence benthic foraminiferal faunas, and faunal changes in the northern Atlantic were generally interpreted as indicative of the presence of less ventilated bottom water masses during glacial periods [e.g., Streeter, 1973; Streeter and Shackleton, 1974; Schnitker, 1974, 1979, 1980; Lohmann, 1978; Balsam, 1981; Murray et al., 1986; Caralp, 1987, 1988]. Many investigators, however, doubt the use of benthic foraminiferal abundances as unequivocal indicators of the physicochemical character of bottom water masses [e.g., Corliss, 1985; Corliss et al., 1986; Thomas and Vincent, 1987, 1988; Linke and Lutze, 1993; Gooday, 1988, 1993; Mackensen et al., 1993a; Schnitker, 1994]. Theoretically, an underlying basis for this concern is the biological observation that the ocean floor is a food-limited environment, in which the nature and biomass of animal communities is largely controlled by the amount of organic matter, derived from surface primary production, that reaches the sediment surface [e.g., Rowe, 1983; Gage and Tyler, 1991]. It therefore appears dubious that the small differences in physicochemical parameters in today's deep water masses could be the dominant determinant of deep-sea benthic foraminiferal assemblages [Thiel et al, 1988; Gooday et al., 1992]. Practically, no consensus has emerged on the relation between specific physicochemical parameters and the abundance of specific species of foraminifera despite many years of studies in all oceans [e.g., Corliss, 1985; Thomas, 1985; Corliss and Chen, 1988; Boltovskoy et al., 1991, 1992; Gooday, 1993, 1994].

Researchers thus considered food supply to the deep-sea faunas as a factor in the assemblage composition [e.g., Corliss et al., 1986; Gooday, 1988, 1993; Loubere, 1991; Miao and Thunell, 1993; Smart et al, 1994]. Note that "food" (organic particulate matter, which can be "eaten" by heterotrophs) must be seen as distinct from nutrients (dissolved inorganic elements such as $\mathrm{N}$ and P) [e.g., Hallock, 1987]. Studies of Recent Uvigerina, for instance, show that a high supply of organic material to the sediments and not the oxygen concentration in the bottom waters is most important in controlling its distribution [Lutze, 1980, 1986; Miller and Lohmann, 1982; van der Zwaan, 1982; Lutze and Coulbourn, 1984; Pedersen et al., 1988; Caralp, 1989; Hermelin and Shimmield, 1990; Hermelin, 1992; Sjoerdsma and van der Zwaan, 1992; Sen Gupta and Machain-Castillo, 1993; Miao and Thunell, 1993; Rathburn and Corliss, 1994], as it is for Melonis spp. [Caralp, 1988, 1989]. The increased abundance of Uvigerina species in the northem and equatorial Atlantic during glacial periods could thus be explained not by changes in deep water circulation patterns, but by the impact of increased glacial productivity on bottom faunas [e.g., Corliss et al., 1986; Caralp, 1989; Sarnthein et al., 1988]. Faunal changes between glacial and interglacial times in the equatorial Pacific have likewise been interpreted as resulting from higher surface productivity during glacial episodes [Pedersen, 1983; Pedersen et al., 1988; Herguera, 1992, 1994; Herguera and Berger, 1991; Herguera et al, 1992; Burke et al., 1993].

The test morphology of the dominant species might also reflect food input and the reactions of organic material in the sediments [Corliss and Chen, 1988; Corliss, 1985]. Uvigerina spp. and Bolivina spp., for instance, are called "tapered cylindrical" [Corliss and Chen, 1988] and thought to have a largely infaunal habitat [Corliss and Emerson, 1990; Corliss, 1991], as reflected in more negative values of $8^{13} \mathrm{C}$ in their tests [McCorkle et al., 1990; Vergnaud-Grazzini and Pierre, 1992]. The abundance of infaunal versus epifaunal taxa is thought to be related to the amount of organic material that reaches the ocean bottom and thus, ultimately, to primary productivity in the overlying surface waters [e.g., Corliss and Chen, 1988; Rosoff and Corliss, 1992].

The situation is complex, however, because benthic foraminifera live at varying depths in the sediment, on the sediment, and on objects sticking out above the sediment surface [Altenbach and Sarnthein, 1989; Corliss, 1991; Linke and Lutze, 1993]. The amount of organic material that reaches the seafloor and consumes oxygen during its oxidation controls the depth of the oxic layer within the sediment, and therefore the maximum depth at which most foraminifera are able to live [Corliss and Emerson, 1990]. In areas where a relatively large flux of organic material reaches the sea floor (such as continental margins under upwelling regions), an Oxygen Minimum Zone develops in the water column, impinging on the bottom [Corliss, 1991; Corliss and Emerson, 1990; Hermelin and Shimmield, 1990]. Al upper bathyal depths and less, and along continental margins, benthic foraminiferal faunas show strong seasonal fluctuations in microhabitats, possibly because the depth and regional extent of the sediment interval with limited oxygen changes seasonally [Jorissen, 1988; van der Zwaan and Jorissen, 1991; Jorissen et al., 1992]. Many species show flexibility as to their exact microhabitats, and adapt to temporal and spatial variations in the flux of organic material [e.g., Altenbach, 1992; Linke and Lutze, 1993; Buzas ei al., 1993]. 
Seasonality has also been shown to be of importance in the deep open oceans, where little organic material reaches the seafloor and lack of food limits the benthic foraminifera largely to the sediment surface [Thiel et al., 1988/89; Gooday, 1993, 1994]. The seasonal pulse results from the springbloom in phytoplankton productivity at midlatitudes, as documented in JGOFS studies and by use of the satellitederived coastal zone color scanner (CZCS) data [e.g., McClain et al., 1993; Yoder et al., 1993]. This seasonal food supply is a major determinant of the species composition of recent benthic foraminiferal faunas in the North Atlantic [Gooday, 1988, 1993, 1994; Gooday and Lambshead, 1989; Gooday and Turley, 1990; Gooday et al., 1992; Lambshead and Gooday, 1990]. Epistominella exigua and Alabaminella weddellensis are small, opportunistic species, and react to the phytodetritus influx by rapidly reproducing and increasing population densities, so that faunal numbrs increase and diversity declines [Gooday, 1988; 1994; Smart et al., 1994]. These two species (wilh typically epifaunal test morphotypes) live on or near the sediment surface, and at times of phytodetritus deposition within the phytodetrital matter. $E$. exigua digests fresh algal cells of the types found in the phytodetritus [Turley et al., 1993].

Dominance of these epifaunal species thus does not indicate an overall low primary productivity and flux of organic material to the seafloor: it indicates an intermittently high, but strongly and unpredictably fluctuating primary productivity, coupled with conditions favorable to the formation of phytodetritus. Such conditions do not necessarily lead to high accumulation rates of organic carbon in the sediments, because in the well - oxygenated bottom waters of today's deep basins organic matter is quickly used by bacteria as well as foraminifera [Lochte and Turley, 1988; Turley and Lochte, 1990]. We can distinguish benthic foraminiferal faunas (with abundant $E$. exigua and $A$. weddellensis, epifaunal morphotypes) that typify regions with a strongly pulsed input of organic material into organic carbon-poor sediments, from faunas (with abundant Uvigerina, Bolivina, Bulimina, and Melonis) that typify regions of high organic productivity and a sustained flux of organic matter to the sea floor, e.g., under areas of upwelling.

We studied benthic foraminiferal faunas in cores recovered as part of the Biogeochemical Ocean Flux Studies (BOFS), at two sites in the northeastern Atlantic Ocean (site 5K: $50^{\circ} 41.3^{\prime} \mathrm{N}, 2^{\circ} 51.9^{\prime} \mathrm{W}$, depth $3547 \mathrm{~m}$; site $14 \mathrm{~K}: 58^{\circ} 37.2^{\prime} \mathrm{N}$, $19^{\circ} 26.2^{\prime} \mathrm{W}$, depth $1756 \mathrm{~m}$; Figure 1). The location of core 5K is presently in southern-source water (derived from Antarctic Bottom Water), $14 \mathrm{~K}$ in lower North Atlantic Deep Water [Manighetti and McCave, this issue, b]. We intended to study the benthic faunas in a region where there is conflict between models, some predicting relatively little glacial to interglacial change in the deep water characteristics [e.g., Labeyrie et al.,

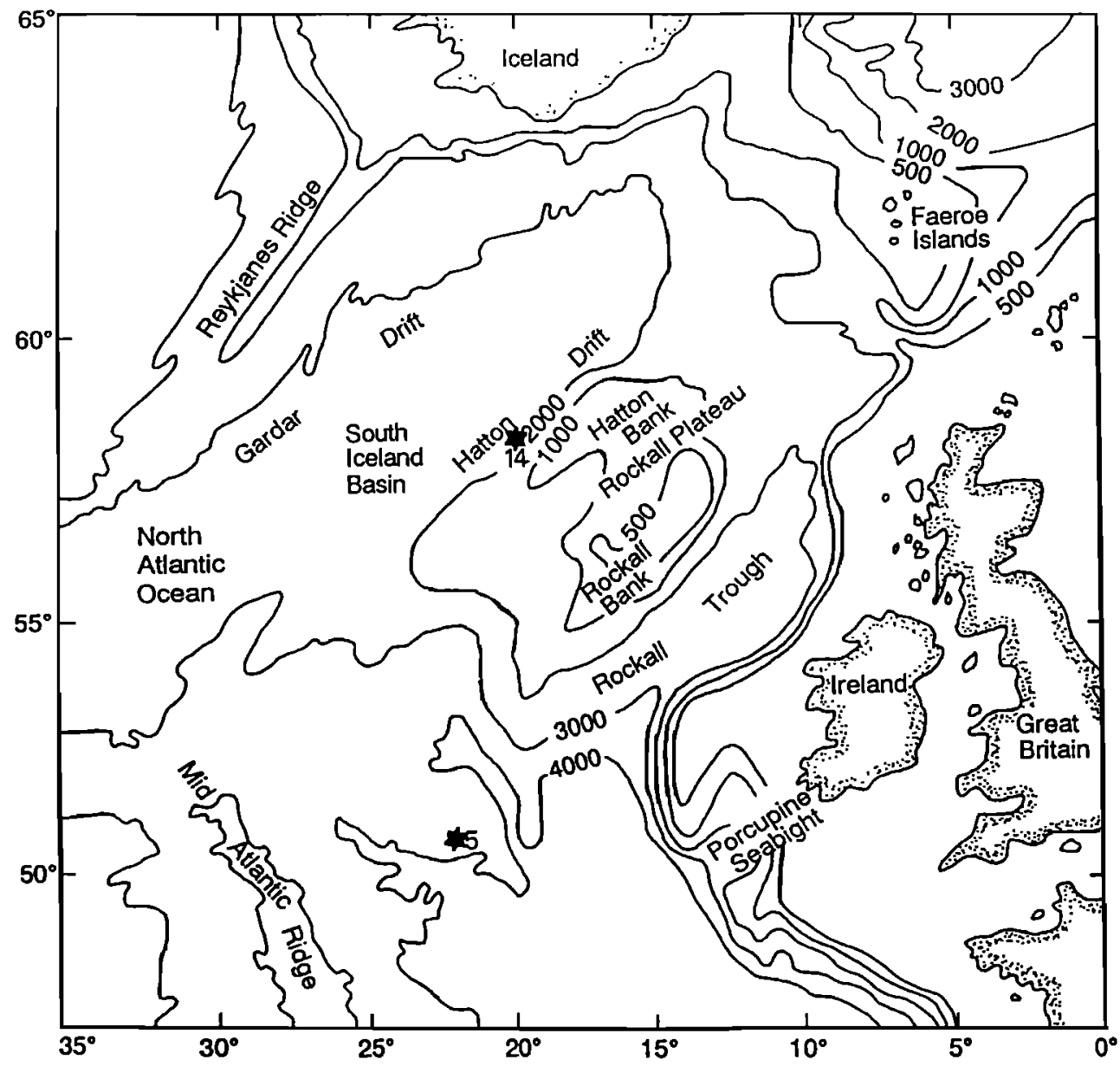

Figure 1. Locations of BOFS cores $14 \mathrm{~K}$ and $5 \mathrm{~K}$. 
1992; Imbrie et al., 1992], and others recognizing less ventilation at depth [Oppo and Lehman, 1993]. Our data, however, show that deep-sea benthic foraminiferal faunas in these regions are indicators of fluctuating surface productivity rather than of deep water circulation.

\section{Methods}

All BOFS cores were sampled in slices of $1 \mathrm{~cm}$ thick, and alternate samples were used for benthic foraminiferal studies. The samples were disaggregated by soaking and gentle shaking in distilled water overnight, and washed through 63 $\mu \mathrm{m}$ sieves. The coarse fraction was dried in an oven at $60^{\circ} \mathrm{C}$ and weighed; the fine fraction was used for sedimentological studies [Manighetti and McCave, this issue, a]. For benthic foraminiferal studies the size fraction $>63 \mu \mathrm{m}$ was used because of the importance of small specimens for paleoecological investigations [Schroeder et al., 1987; Thomas, 1985; Gooday, 1988, 1993; Boltovskoy et al, 1992], although we realized that comparison between our results and those from studies using the $>125,>150$, or even $>250 \mu \mathrm{m}$ size fraction will present problems.

Chronology for the cores was provided by oxygen isotope data, tephrachronology, and AMS ${ }^{14} \mathrm{C}$ dates [Maslin, 1993; Manighetti et al, this issue]. The sedimentation rate for core $5 \mathrm{~K}$ varied between 4.4 and $10.6 \mathrm{~cm} / \mathrm{kyr}$, resulting in a sample resolution of about 250 years. For core $14 \mathrm{~K}$ the sedimentation rates varied from 1.5 to $6 \mathrm{~cm} / \mathrm{kyr}$; the age model for this core is not as reliable as that for core $5 \mathrm{~K}$, and several intervals appear to have very low sedimentation rates [Manighetti et al., this issue; Maslin et al, this issue].

Deep-sea benthic foraminiferal faunas are diverse and contain a large proportion of rare species [e.g., Douglas and Woodruff, 1981]. Therefore one must establish the minimum number of specimens needed to obtain a reliable estimate of the species richness (number of species per sample). We obtained rarefaction curves (number of species versus number of specimens; Sanders, 1968) for several samples from glacial and interglacial intervals. Species-specimen curves become parallel to the species-axis at about 180 specimens, and thus we decided to pick at least 200 specimens per sample. This number is similar to that obtained by Thomas [1985] for late Paleogene to Neogene samples from the equatorial Pacific and the northern Atlantic Ocean [Thomas, 1986a, b].

For benthic foraminiferal studies one strewing in a picking tray was investigated to estimate the abundance of benthic foraminifera in the sample. A microsplitter was used to obtain a split of such a size that one would expect to find 200 or more specimens. All benthic foraminifera were then picked from the split; if the number tumed out to be less than 200 additional splits were made and picked until 200 specimens were oblained. This proved to be possible in almost all samples. We compared the changes in relative abundance with those in absolute abundances (number of benthic foraminifera per gram), because the former suffer from the "fixed sum" problem: an increasing percentage of one abundant species will automatically result in decreasing percentages of other abundant species.

The abundance of benthic foraminifera (number of specimens per gram) varied by more than three orders of magnitude (i.e., by much more than the sedimentation rates).
Numbers per gram are given for the larger than $63 \mu \mathrm{m}$ size fraction from which the foraminifera were picked. For the last 28,000 years the numbers could be calculated to numbers per gram of total dry sediment, and in benthic foraminiferal accumulation rates, using data by Manighetri et al. [this issue] and Manighetti and McCave [this issue, a]. Benthic foraminiferal accumulation rates (BFARs) have been used to estimate export of organic matter to the seafloor [Herguera and Berger, 1991; Herguera, 1992, 1994; Berger et al., 1994]; at equal productivity, deeper sites can be expected to receive less organic matter and thus have a smaller BFAR than shallower sites. All counts of benthic foraminifera are available on the BOFS North Atlantic Dataset CD-ROM, available from the British Oceanographic Data Centre. The taxonomy largely follows Thomas [1985, 1986a], and will be discussed in more detail in a separate paper [E. Thomas, L. Booth and N. J. Shackleton, manuscript in preparation, 1995].

\section{Results}

The relative and absolute abundance data for the most common benthic foraminiferal taxa in cores 5K (Figures 2 and 3) and $14 \mathrm{~K}$ (Figures 4 and 5) show major differences belween glacial and interglacial periods in core $5 \mathrm{~K}$. In the shallower core 14K faunal changes are not coeval with deglaciation; in both cores faunal changes on time scales of hundreds to thousand year are common. The total relative abundance of buliminid, cassidulinid and Pullenia species (Figure 6a) decreased during deglaciation in core $5 \mathrm{~K}$. High relative abundances of these species have been linked to the occurrence of waters with a relatively low oxygen content (Schnitker, 1984; Kaiho, 1994). This faunal pattern might thus be seen as evidence that waters at $5 \mathrm{~K}$ were less ventilated during glacial isotope stage 2 and interglacial stage 3 . The species, however, have also been described as indicative of a high rate of deposition of organic matter to the sea floor [e.g., Corliss and Chen, 1988; Corliss and Emerson, 1990], and one can thus also explain the data as a resulting from higher surface water productivity during glacial intervals [Corliss et al., 1986].

High glacial productivity at the location of $5 \mathrm{~K}$ and $14 \mathrm{~K}$, however, is not supported by other evidence. The relative abundance of the planktonic foraminiferal species $\boldsymbol{G}$. bulloides, a high-productivity indicator, and its $\delta^{13} \mathrm{C}$ record, suggest that surface productivity was low to very low during glacials at the location of cores $14 \mathrm{~K}$ and $5 \mathrm{~K}\left(50^{\circ}-60^{\circ} \mathrm{N}\right)$ [Maslin, 1993; Maslin et al., this issue]. In addition, absolute abundances of the "low oxygen" species increased during deglaciation (Figure 6); the decrease in relative abundance is caused by the enormous increase in relative as well as absolute abundance of the "phytodetritus species" Epistominella exigua and Alabaminella weddellensis (Figure 7). Specimens of these two species make up a very large part of the total fauna (Figure 8): when numbers of total benthic foraminifera are high $(>1000 / \mathrm{gr})$, these species have high relative abundances. The only exception is a short period at about $37-40 \mathrm{kyr}$ (Figure 8).

The fluctuations in absolute abundance of the "phytodetritus species" range over two orders of magnitude, i.e., far out of the range of changes in accumulation rate of the sediments [Manighetti et al., this issue]. These changes thus must have been caused by changes in the productivity of benthic foraminifera, not by fluctuations in the dilution of the benthic 

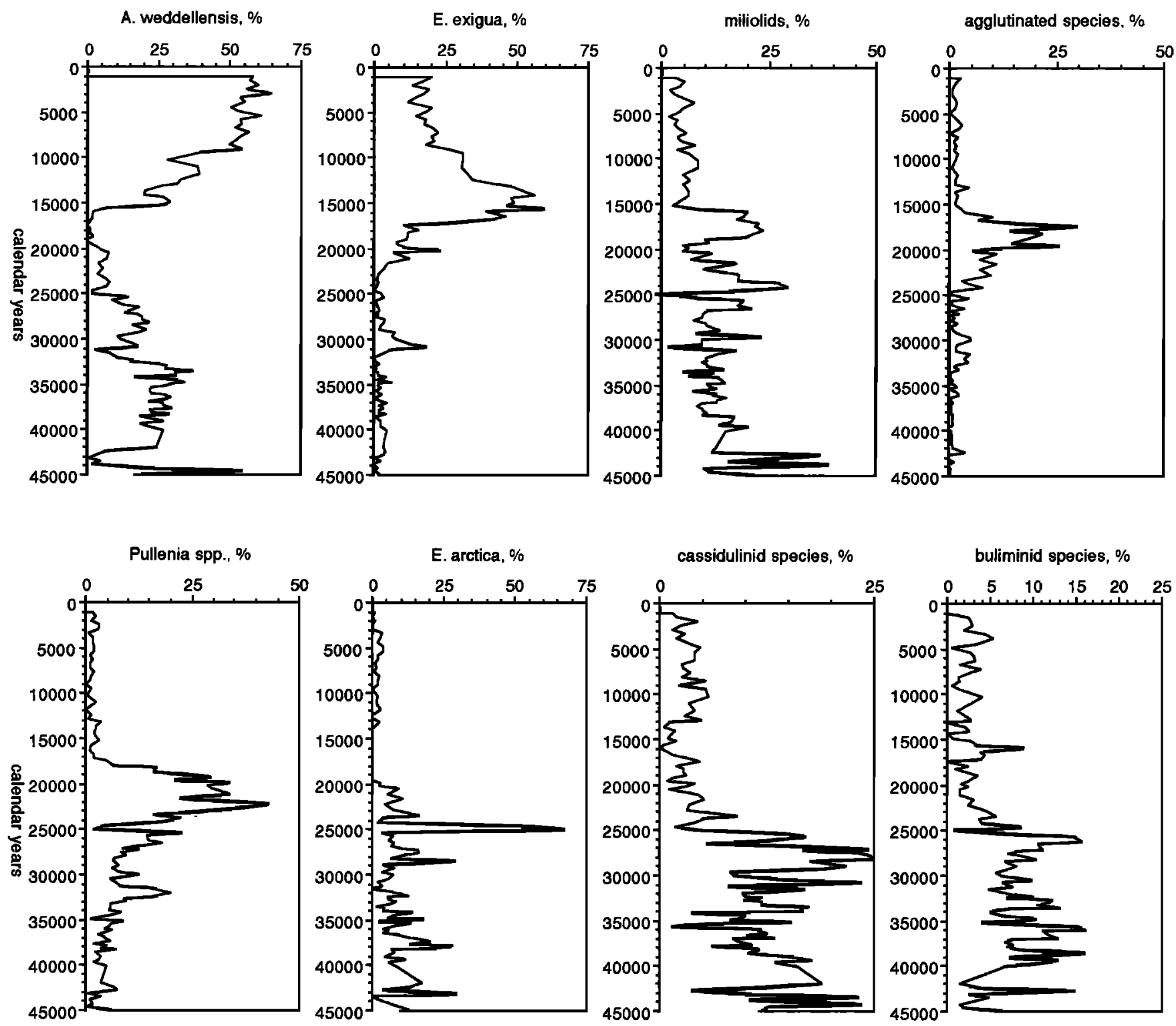

Figure 2. Relative abundances of the most common benthic foraminiferal taxa in core 5K. Ages after Manighetti et al. [this issue].

foraminifera with terrigenous or planktonic foraminiferal material. Our data on benthic foraminiferal accumulation rate (BFAR) for the last $28 \mathrm{kyr}$ confirm that high BFARs occurred at times of high relative and absolute abundance of the "phytodetritus species" (Figure 9). In 5K the species richness decreased when the abundance of the phytodetritus species increased (Figure 9a).

The lowest BFAR as well as absolute abundance occurred during the last glacial maximum (oxygen isotope stage 2) at both sites (Figure 9c). At 14K the BFAR as well as the relative abundance of "phytodetritus species" during oxygen isotope stage 3 was higher or as high as during isotope stage 1, but at 5K the abundance was much higher since the last deglaciation. Since deglaciation the BFAR has been about equal at both sites (Figure 9c), implying that productivity was higher at the deeper site [Herguera and Berger, 1991; Berger et al., 1994].
During isotope stages 2 and 3 the BFAR was higher at the shallower site, as expected. At 5K the BFAR, the total benthic absolute abundance, and the abundance of the "phytodetritus species" decreased during the Younger Dryas (Figures 7 and 9). The record at $14 \mathrm{~K}$ has a low time-resolution, but a similar signal may be present.

The total of "phytodetritus species" was at different times dominated by $A$. weddellensis or by $E$. exigua at sites $5 \mathrm{~K}$ and $14 \mathrm{~K}$. We cannot offer an explanation for this phenomenon (Figures 3 and 4), because from studies of Recent faunas no difference in environmental preference between the two species is known.

We conclude that the fluctuations in absolute and relative abundances of the "phytodetritus species" should be explained as resulting from changes in intensity of the spring blooms of phytoplankton productivity, which produces phytodetritus 

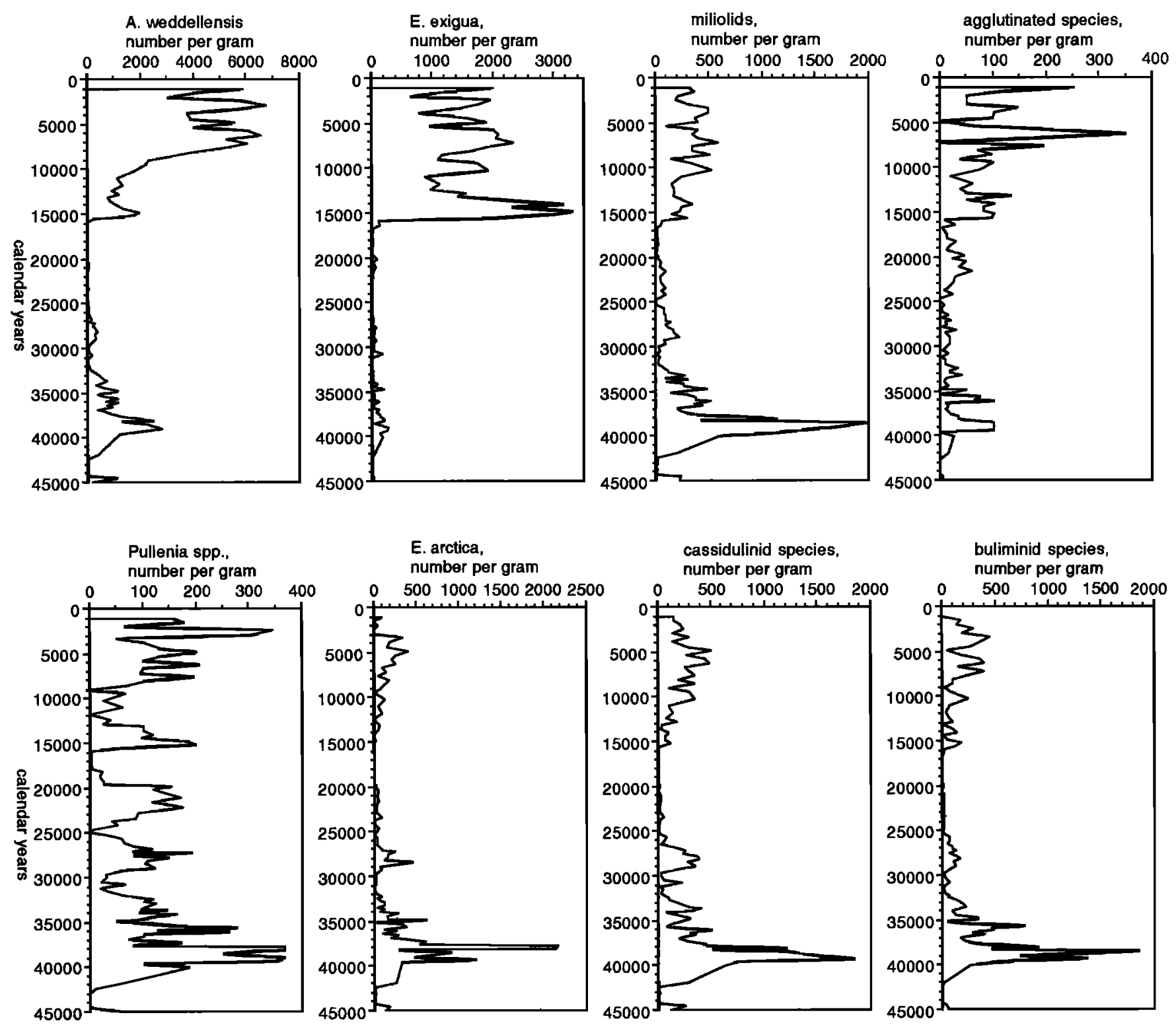

Figure 3. Absolute abundances (in number per gram) of the most common benthic foraminiferal taxa in core 5K. Ages after Manighetti et al. [this issue].

deposition on the seafloor. At present, "phytodetritus species" are abundant below waters to the south of the polar front [Gooday et al., 1992; Gooday, 1993]. We suggest that the southern border of their abundant occurrence moved north and south over the seafloor during glacial-interglacial transitions, following the polar front (as reconstructed in e.g., Lehman and Keigwin, 1992; Veum et al, 1992). The organic carbon content of the sediments [Manighetti and McCave, this issue, a] was overall low (0.2-0.7\%), and shows no systematic change and no correlation with the BFAR.

The explanation that the benthic faunas followed the migration of the polar front is supported by comparison of the relative abundances of "phytodetritus species" with that of the planktonic foraminiferal species $N$. pachyderma (s), a polar waler indicator, and that of $G$. bulloides, an indicator of spring blooms (Figure 10) [Maslin, 1993]. Relative abundances of the polar planktonic species were high, and relative abundances of $G$. bulloides were low at times when the "phytodetritus species" had low relative abundances. The only exception is again the short interval at about $37-40 \mathrm{kyr}$, with very low abundances of $N$. pachyderma (s), high relative abundances of $G$. bulloides, and high total abundances of benthic foraminifera, but only a moderate abundance of "phylodetritus species". Dominant benthic species at that time were the "low oxygen" taxa (Figure 3), as well as the Arctic species Epistominella arctica (s.1.).

Is there a residual benthic foraminiferal signal at sites $5 \mathrm{~K}$ and $14 \mathrm{~K}$, suggesting that changes in deep water ventilation during the last glacial are reflected in the faunas? If we subtract the percentage of phytodetritus species from the total fauna, we can normalize the relative abundances of all other species to this new total, in order to attempt a look at faunal patterns 

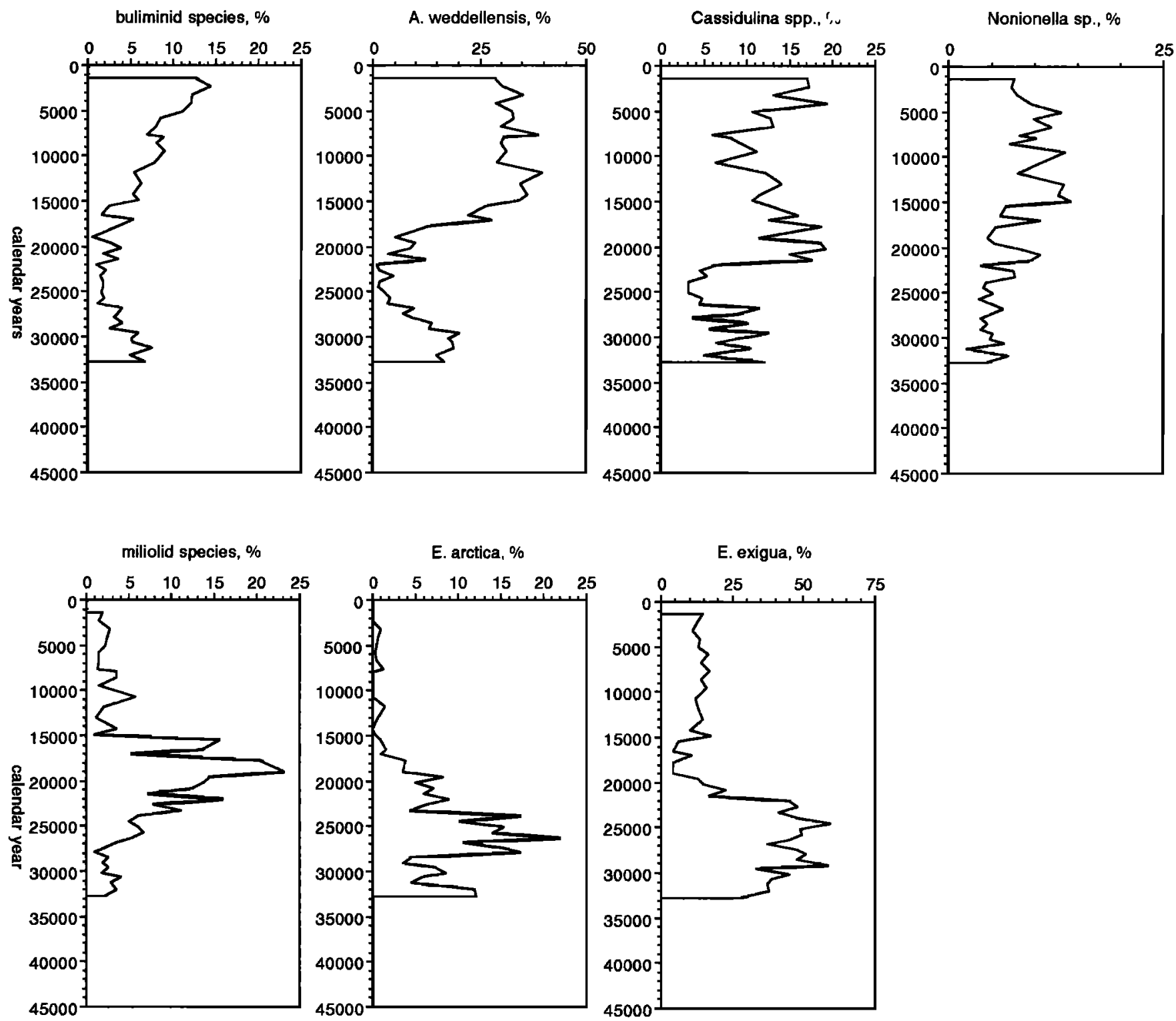

Figure 4. Relative abundances of the most common benthic foraminiferal taxa in core 14K. Ages after Manighetti et al. [this issue].

without the "phytodetritus species" (Figure 11). The "corrected abundance" of the "low oxygen" species shows a decrease at deglaciation at $5 \mathrm{~K}$; at $14 \mathrm{~K}$ these species had their lowest abundance between 22 and $27 \mathrm{kyr}$. We can not interpret high relative abundances of these species as indicative of high deposition of organic matter, as explained above. Therefore their higher glacial abundance could be seen as suggestive of more sluggish circulation during the last glacial maximum as well as during oxygen isotope stage 3 at $5 \mathrm{~K}$. The evidence for this conclusion is not strong, however, because of the very small numbers of specimens belonging to non-"phytodetritus species" after deglaciation.

Another feature of the faunal record at 5K is the increase in relative abundance and diversity of agglutinated species during deglaciation (Figures 2 and 3), while their absolute abundance did not increase. Some of these species have been mentioned as dominating in regions with relatively high bottom currents in the present oceans [Linke and Lutze, 1993]. This faunal pattern could thus possibly be seen as evidence for increased vigor of bottom currents at the deepest site during deglaciation [Duplessy et al., 1991; Imbrie et al., 1992]. The percentage of agglutinated species (Figure 2), however, faithfully mimics the flux of coarse non-carbonate material at the site [Manighetti and McCave, this issue, a, Figure 4). These authors interpret this material as being ice-rafted; it appears thus as if high relative abundances of agglutinated species occurred during times of increased ice-rafting, and thus increased supply of non-carbonate grains.

The very poor benthic faunas in the Heinrich layers (especially in layer H3) contain specimens of very large, heavy-walled, and abraded Elphidium excavatum. There has been considerable discussion regarding the depth habitat of 

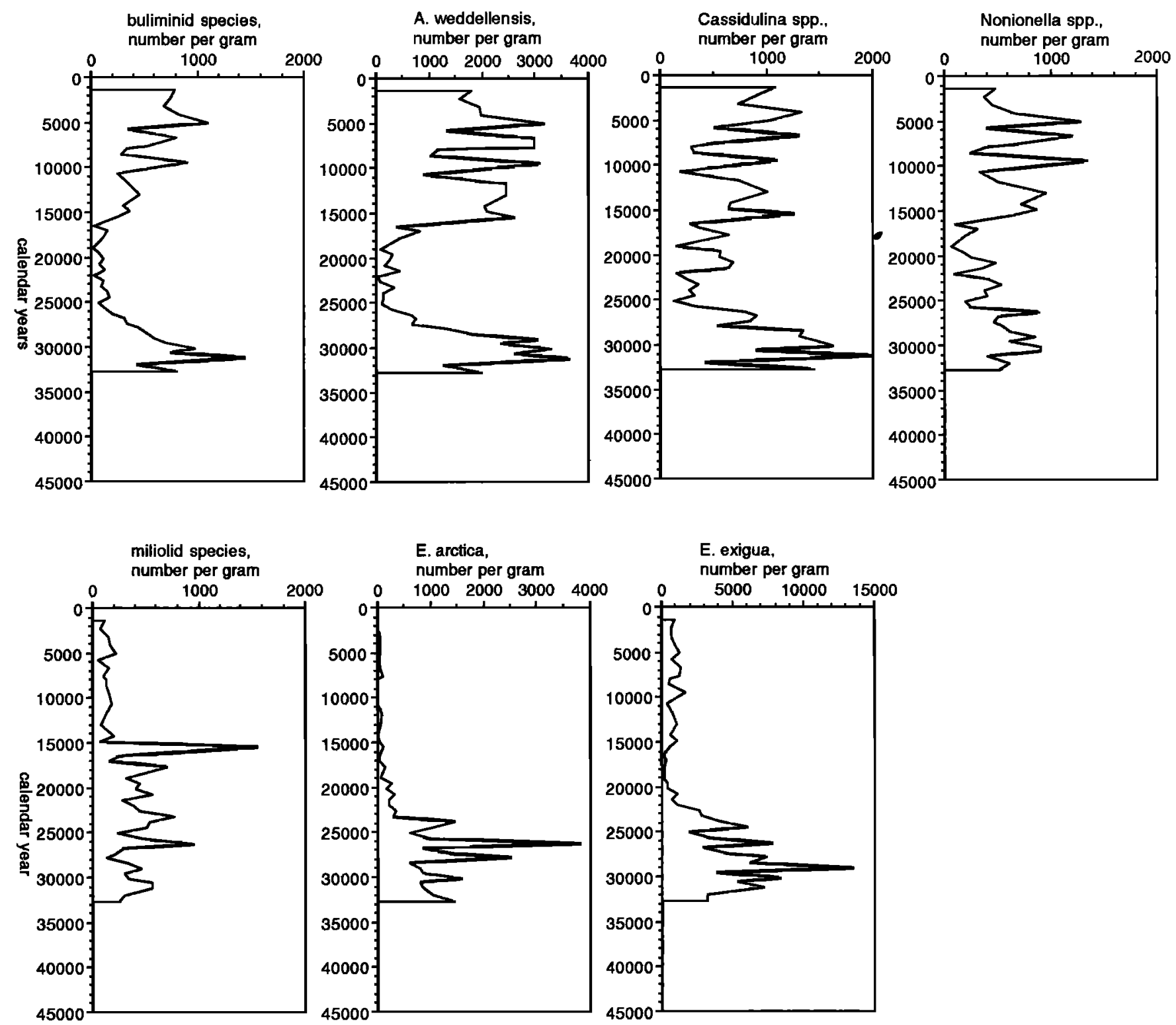

Figure 5. Absolute abundances (in number per gram) of the most common benthic foraminiferal taxa in core 14K. Ages after Manighetti et al. [this issue].

this species, which according to some authors is a neritic to shelf species [Sejrup et al., 1981; Mackensen et al., 1985], whereas others maintain that it has a very large depth range [Corliss, 1991]. We agree that the species almost certainly has a very large depth range: in many samples specimens are very similar in preservation to all other specimens present, and are relatively small and thin-walled. The large, heavywalled and abraded specimens, however, were probably transported by ice rafting.

The faunal composition at $5 \mathrm{~K}$ at $37-41 \mathrm{kyr}$ is difficult to explain: benthic foraminifera were very abundant, but not the "phytodetritus species". The predominance of the "low oxygen" species at that time of high surface water temperatures [Maslin et al., this issue] could be seen as resulting from low rates of ventilation, but this interpretation conflicts with the interpretation of coeval high density of the surface waters by these authors. They concluded that exactly that period might have had deep water formation in the northeastern Atlantic. The warm period might have had increased, year-round (instead of pulsed) deposition of organic material to the seafloor. The occurrence of this short peak demonstrates the great variability of benthic foraminiferal faunas at shorter time scales than orbital frequencies, and the dangers of making overall conclusions as to deep oceanic environments using data at low time- resolution.

\section{Discussion}

The dominant glacial-interglacial changes in deep-sea benthic foraminiferal faunas at northeastern Atlantic core sites 

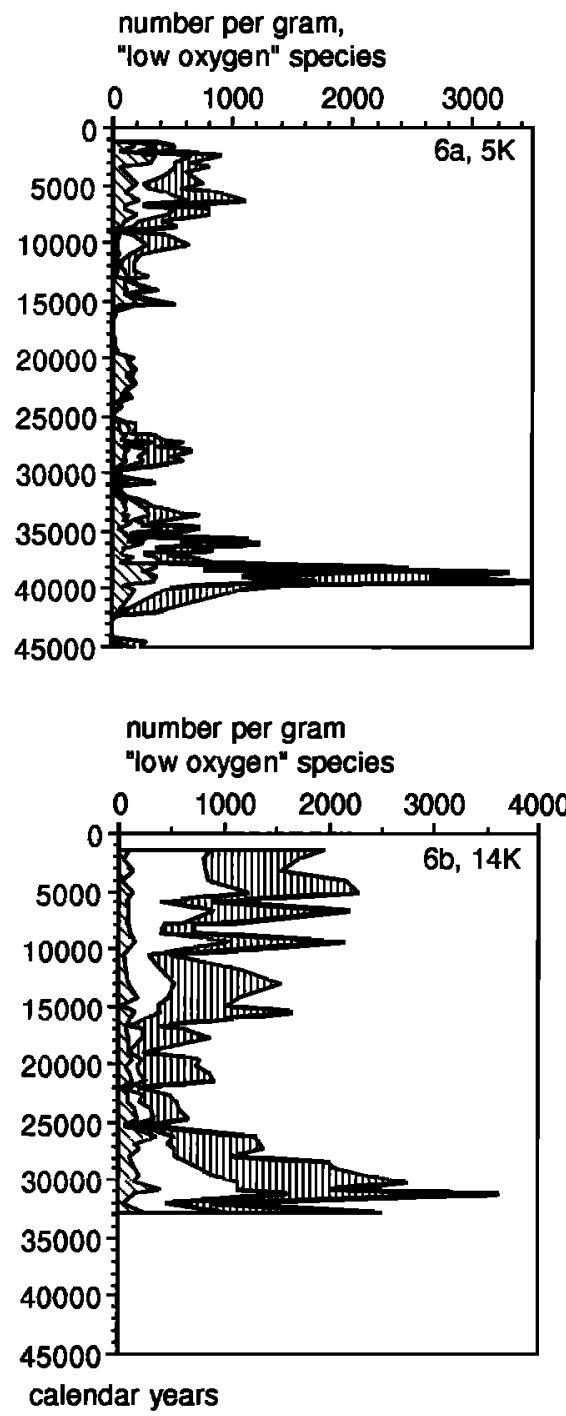

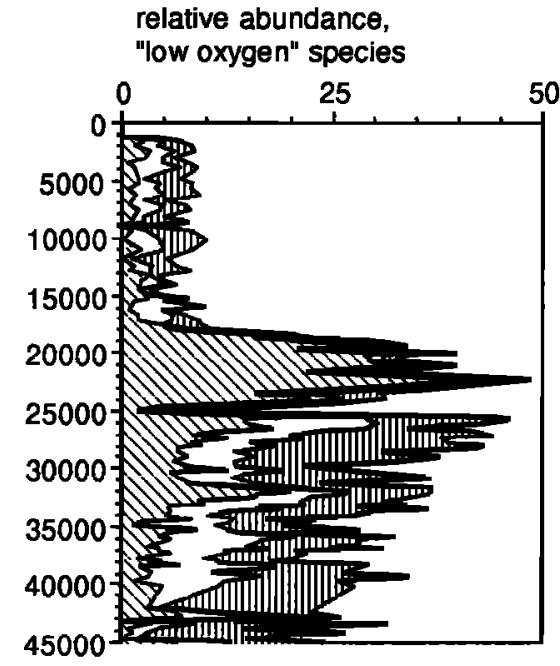

relative abundance, "low oxygen species"

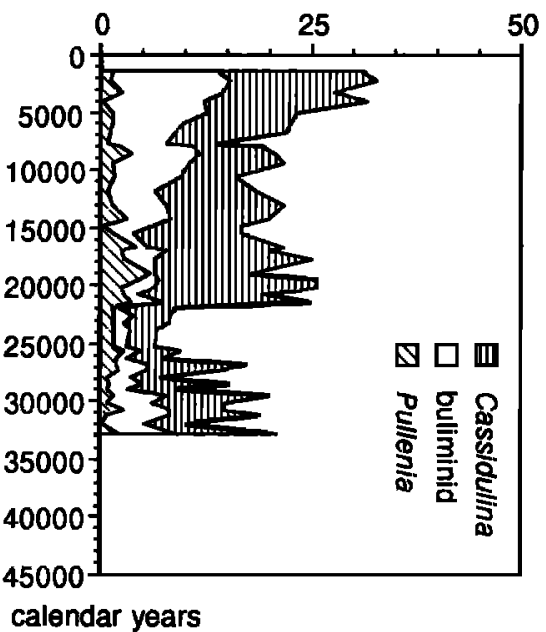

Figure 6. Relative and absolute abundances of the "low-oxygen" or "high organic carbon" taxa, Pullenia spp., Cassidulina spp., and species belonging to the Buliminacea; (a) 5K; (b)14K.

5K and $14 \mathrm{~K}$ appear to be related to changes in the amount of phytodetritus deposited to the seafloor (and thus probably to surface water productivity), rather than to changes in the physicochemical character of deep waters, in agreement with e.g., Corliss et al. [1986], Corliss [1991], and Mackensen et al. [1993a, b, 1994]. Our data indicate that surface water productivity in the northeastern Atlantic at high latitudes to midlatitudes $\left(50^{\circ}-58^{\circ} \mathrm{N}\right)$ was lower during glacial intervals than during interglacial intervals. The benthic foraminiferal evidence for lower productivity in the northeastern Atlantic during glacial intervals is supported by evidence from organic carbon content in sediments on Feni Drift $\left(54^{\circ}-56^{\circ} \mathrm{N}\right)$ [van Weering and de Rijk, 1991], and by data on the organic geochemistry of sediments in the same area [Jasper et al., 1993]. The globally higher surface water productivity during glacial periods thus must have occurred in lower latitude regions, such as the equatorial Atlantic and Pacific (Pedersen, 1983; Pedersen et al., 1988; Sarnthein et al., 1988, Herguera, 1992; Herguera and Berger, 1992, 1994; Burke et al., 1993;
Murray et al., 1993; Berger et al., 1994). At high latitudes in the Southern Oceans productivity was also lower during glacials (Berger and Wefer, 1991; Charles et al., 1992; Mortlock et al., 1991; Kumar et al., 1993; Shemesh et al., 1993; Francois et al., 1993).

We do not conclude that high abundances of "phytodetritus species" indicate high productivity as compared to typically high-productivity regions; we discussed only effects on a midocean fauna in an overall low-productivity region. On continental margins overall productivity is higher and the flux of organic matter to the seafloor is more continuous; in these regions the organic carbon content of the sediments is commonly high (Miao and Thunell, 1993; Rathburn and Corliss, 1994), and positively correlated with the BFAR. High abundance of the "phytodetritus species" species appears to indicate occasionally high, but pulsed, unpredictable and non continuous deposition rates of organic matter to the seafloor; in such regions the BFAR may not be positively correlated with the organic carbon content of the sediments. We may 

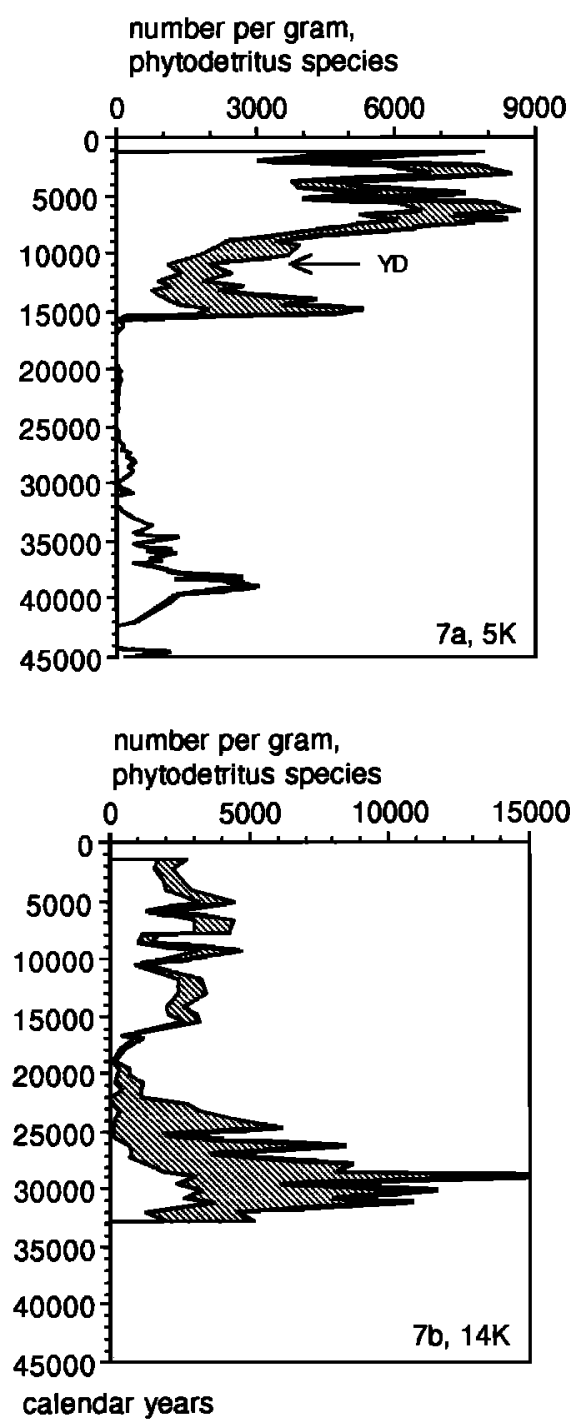

relative abundance, phytodetritus species

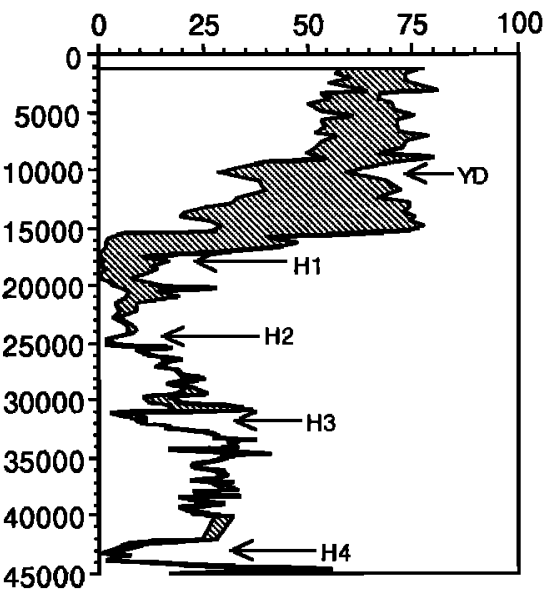

relative abundance, phytodetritus species

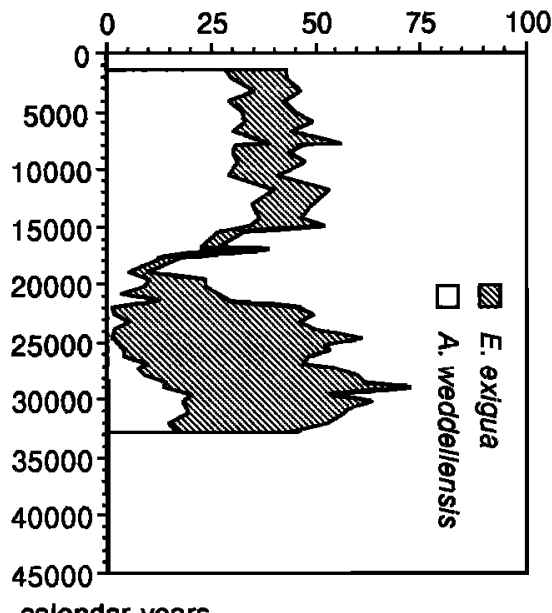

Figure 7. Relative and absolute abundances of $E$. exigua and $A$. weddellensis, the "phytodetritus species"; (a) 5K; (b) $14 \mathrm{~K}$

have to reinterpret published benthic foraminiferal faunal analyses as resulting from a complex interaction between bottom water characteristics and surface water productivity. For instance, the high relative abundance of $E$. exigua during the last glacial at DSDP Site $594\left(45^{\circ} 31.41^{\prime} S\right)$ may have resulted not from cooling of bottom waters but from increasing and highly fluctuating productivity [Nelson et al., 1993].

During glacial/interglacial transitions the northeastern Atlantic benthic foraminiferal faunas thus appear to follow not the boundaries of deep water masses moving along the seafloor, but the Polar Front in the surface waters. This could offer an alternative explanation for the data shown by Schnitker [1974], who demonstrated that faunas with common to abundant $E$. exigua in the western Atlantic retreated to more southern waters during the last glacial maximum, when $N$. pachyderma (s) extended its range southward to about $40^{\circ} \mathrm{N}$ [Kipp, 1976; McIntyre et al., 1976]. It is not clear exactly at what latitude the boundary was between the region with higher productivity during glacial maxima, and the region with lower productivity during glacials (i.e., the polar front). One would expect that the southern boundary of the region with low glacial deposition of phytodetritus is somewhere between $40^{\circ}$ and $50^{\circ} \mathrm{N}$, at the location of the strong gradient in relative abundance of the polar planktonic foraminiferal assemblage [McIntyre et al., 1976, Figure 3]. The location of this gradient, however, is not well constrained by data points. Corliss et al. [1986] suggested that Uvigerina abundances indicate higher glacial productivity in the northwestern Atlantic, with most data quoted [Streeter and Shackleton, 1979; Schnitker, 1980; Balsam, 1981; Streeter and Lavery, 1982] from $45^{\circ} \mathrm{N}$ or lower latitudes, and located along the continental margin. Faunas in core V29-179, on the eastern side of the Mid Atlantic Ridge at $44^{\circ} \mathrm{N}$ and a depth of $3331 \mathrm{~m}$, were dominated by $E$. exigua after deglaciation [Streeter and Shackleton, 1979]. Schnitker [1979, 1980] demonstrated that $E$. exigua had a higher relative abundance after deglaciation in core V26-176 (at $36^{\circ} 03^{\prime} \mathrm{N}, 72^{\circ} 23^{\prime} \mathrm{W}, 3942 \mathrm{~m}$, on the eastern 

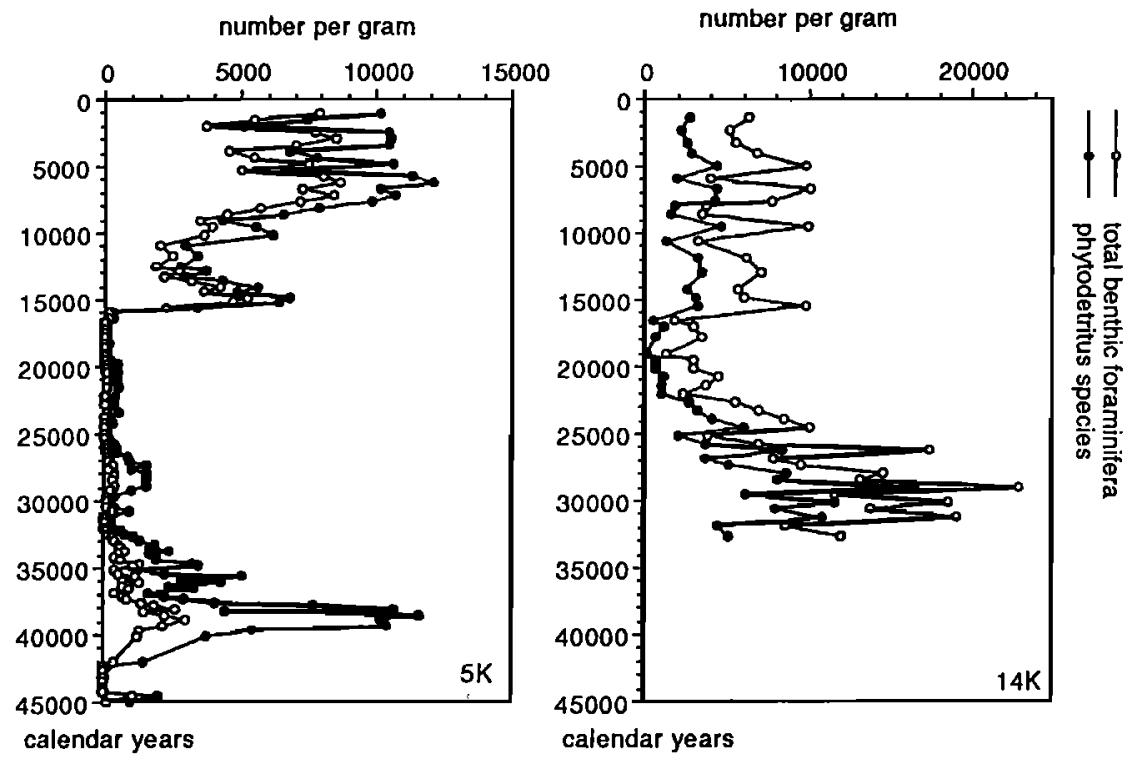

Figure 8. Absolute abundances of the "phytodetritus species" compared to the total benthic foraminiferal absolute abundance, cores $5 \mathrm{~K}$ and $14 \mathrm{~K}$.

US slope), but the reverse is true in core GPC $5\left(33^{\circ} 59.3^{\prime} \mathrm{N}\right.$, $57^{\circ} 37.5^{\prime} \mathrm{W}, 4583 \mathrm{~m}$, on the Bermuda Rise). The glacial Polar Front was thus probably somewhere between $45^{\circ}$ and $36^{\circ} \mathrm{N}$, but its exact shape is not known. In the present oceans, areas of high phytodetritus productivity are patchy (McClain et al., 1993; Yoder et al., 1993), so we need high geographical sample density to map such areas; unfortunately, we can no longer aim at the prediction of the faunal content of large water masses.

Heinrich events were periods with greatly increased numbers of icebergs, especially in the zone of maximum ice rafting [Ruddiman, 1977], as deduced form very high abundances of ice-rafted material [Heinrich, 1988; Grousset et al., 1993]. It has been suggested that the low abundance of planktonic foraminifera in Heinrich-event sediments resulted from greatly decreased surface water productivity [Broecker et al., 1992; Bond et al., 1992], but the low abundance could have resulted from greatly enhanced input of ice-rafted material. In the benthic foraminiferal records from core $5 \mathrm{~K}$ Heinrich events can be seen in the records of absolute as well as relative abundances of the "phytodetritus species", which are extremely low during all the Heinrich events (Figures 2, 3 and 6); BFARs are also very low (Figure 9). This supports the interpretation of these events as very low-productivity events [Broecker et al., 1992; Bond et al., 1992], but appears to be in conflict with the suggestion that diatom productivity could have been high in the waters directly surrounding melting icebergs ("ice edge" effect) [Sancetta, 1992].

During Heinrich event 2 E. arctica (s.l.) had a very high relative, not absolute abundance at 5K (Figures 2 and 3). We cannot explain this occurrence: possibly the species can survive the very low surface productivity events better than other species. It is the dominant species at depth in the Arctic Ocean, where productivity is extremely seasonally limited [Lagoe, 1977, 1979; Belanger and Streeter, 1980; Scott and Vilks, 1991]. Its dominance in the Arctic can not be explained by physical factors, and has been attributed to unspecified "biological factors" [Lagoe, 1979]. We speculate that such a biological factor could be the extremely short period of pulsed food input into the deep ocean, so extreme that the "phytodetritus species" can not bloom. Maybe E. arctica (s.1.) can react to the summer food influx by very rapid growth and reproduction, as recorded to occur in some species [Altenbach, 1992].

In the modern ocean absolute and relative abundances of "phytodetritus species" are higher at the deeper site 5K than at the more northern and much shallower site $14 \mathrm{~K}$, suggesting that spring bloom activity is intense at the deeper site $5 \mathrm{~K}$. During isotope stages 2 and 3 , however, the situation was reversed, with higher numbers at the shallower site $14 \mathrm{~K}$, the expected pattern [Herguera, 1992]. Data on the planktonic foraminiferal species abundances and derived sea surface temperatures [Maslin, 1993; Maslin et al., this issue] suggest that surface waters were warmer at $14 \mathrm{~K}$ than at $5 \mathrm{~K}$, possibly because $5 \mathrm{~K}$ was in the zone of maximum ice rafting [Grousset et al, 1993], possibly because $14 \mathrm{~K}$ received a flow of warmer surface waters, moving in a gyral pattern from the southeastern North Atlantic northwards. The abundance patterns of "phytodetritus species" could thus be used to reconstruct locations of higher spring-bloom activity in the past.

In our cores the effects of changing spring-bloom activity are very strong, and overwhelm all or almost all possible effects on the fauna of changing bottom water ventilation, which may not be true for other sites. Models of deep water formation [e.g., Heinze et al., 1991; Labeyrie et al., 1992; Imbrie et al., 1992] indicate that only minor changes in deep water circulation are expected to have occurred at the location of 5K and $14 \mathrm{~K}$, because these sites are far north, and would have received northern-derived waters even during peak glacial conditions. Other reconstructions, however, do suggest ventilation changes at these far northem latitudes [Oppo and 

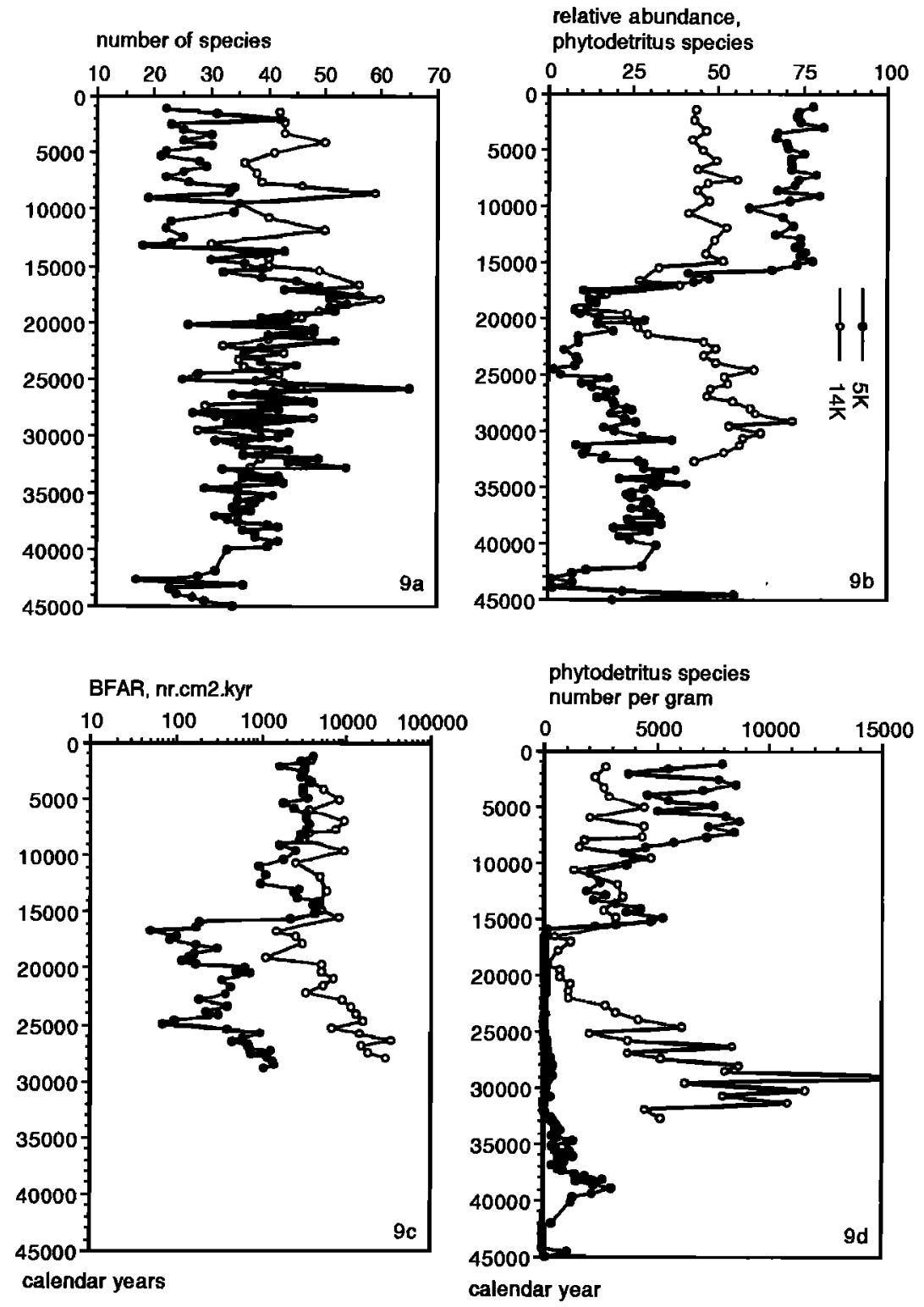

Figure 9. Comparison of (a) species richness, (b) relative abundance of phytodetritus species, (c) benthic foraminiferal accumulation rates (BFAR) and (d) absolute abundance of "phytodetritus species" at $14 \mathrm{~K}$ and 5K. Note that the BFAR plot has a logarithmic scale.

Lehman, 1993]. Our data suggest at least tentatively that this might be true. At locations where changes in the character of deep waters were more pronounced, circulation effects might be more pronounced than productivity effects.

In evaluating published data we must realize that most authors studied the $>125$ or $>150 \mu \mathrm{m}$ size fraction, while most specimens of the "phytodetritus species" are in the 63-125 $\mu \mathrm{m}$ size range [Gooday, 1988]; in contrast, the average size of Uvigerina and Cibicidoides species is larger than $125 \mu \mathrm{m}$. Some individuals, especially of $E$. exigua, are in the $>125 \mu \mathrm{m}$ size fraction, and this species has been shown to contribute significantly to glacial-interglacial differences [Schnitker, 1974, 1979, 1980; Streeter and Shackleton, 1979; Nelson et al., 1993]. Therefore part of the signal in $>125 \mu \mathrm{m}$ faunas results from changes in the deposition of phytodetritus, and the signal is a mixture of changes in deep water characteristics, phytodetritus deposition and surface water productivity [Mackensen et al., 1993a, 1994; Berger et al., 1994]. It is probably possible to exclude the "phytodetritus species" completely by considering only the $>\mathbf{2 5 0} \mu \mathrm{m}$ size fraction [Lohmann, 1978; Caralp, 1988]. This results, however, in the presence of very small numbers of individuals in many samples, and it is questionable whether such small populations can give us information on environmental changes [Schroeder et al., 1988].

A problem in the interpretation of isotope, trace element and faunal data could be caused by the possibility that changes in surface water productivity at least partially caused changes 


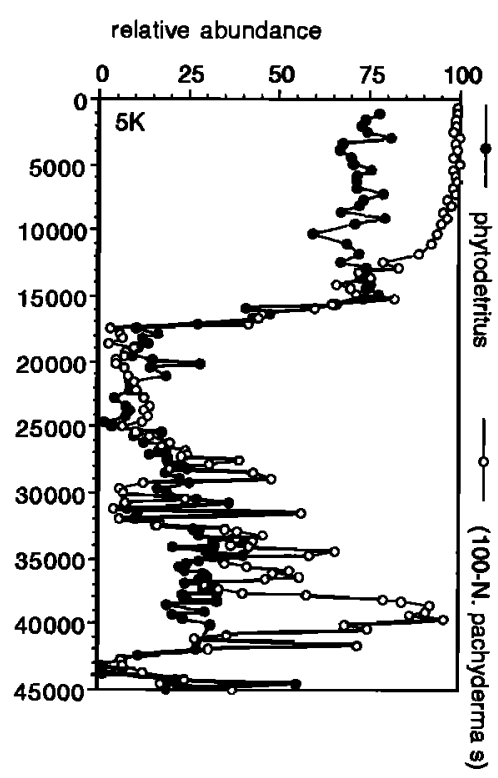

relative abundance
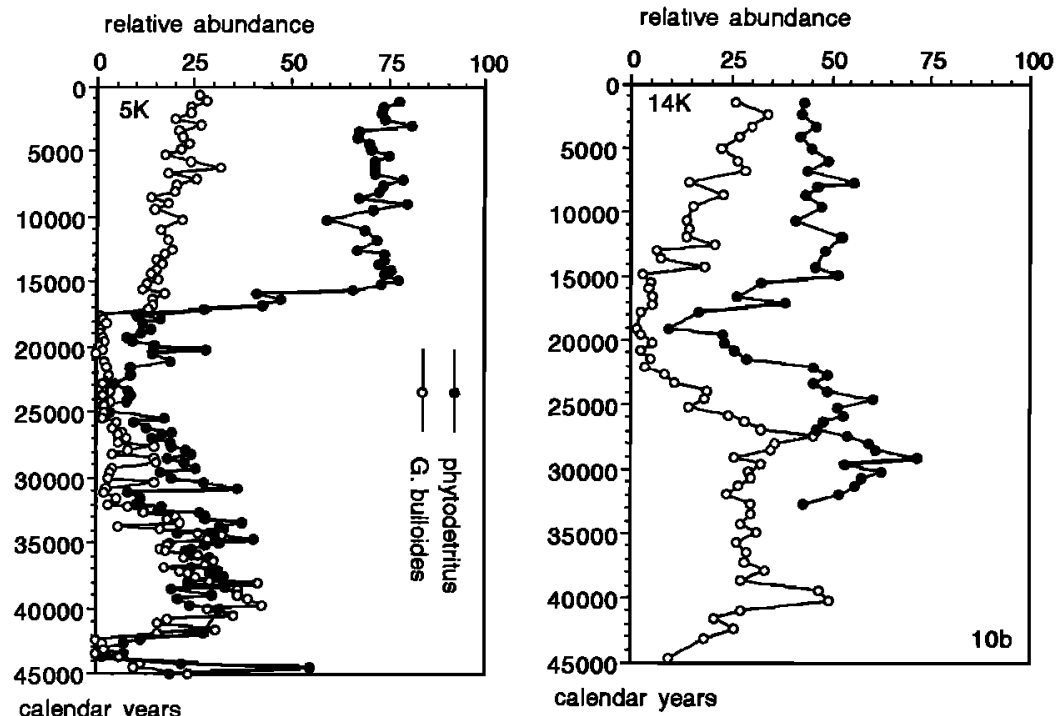

Figure 10. Comparison of the relative abundance "phytodetritus species" and the relative abundance of planktonic species in $5 \mathrm{~K}$ and 14K; (a) Relative abundance of the polar planktonic foraminifer species $N$. pachyderma (s). Note that $100-\% N$. pachyderma (s) is plotted. (b) Relative abundance of the warm water planktonic foraminifer species $G$. bulloides.

in, thus possibly discrepancies between, proxy parameters used to estimate the extent of deep water ventilation (such as $\Delta \delta^{13} \mathrm{C}$ and $\mathrm{Cd} / \mathrm{Ca}$ in bottom waters), as was suggested by $\mathbf{M i x}$ and Fairbanks [1985] for the northern Atlantic Ocean and by Mackensen et al. [1993b] for the Southern Ocean. Results from the JGOFS program show the enormous extent of the annual spring blooms of the North Atlantic, and thus suggest that very large amounts of organic material are formed [e.g., McClain et al., 1993; Yoder et al., 1993]. It is at least conceivable that the amount of preformed nutrients changed considerably during glacials, when the spring blooms were confined to lower latitudes. Much depends on the place where deep or intermediate waters formed during glacials [e.g., Imbrie et al, 1992]. If this location moved southward, close to the region where spring-blooms could take place, less of an effect on the preformed nutrients is expected. We suggest, however, that observations on $\delta^{13} \mathrm{C}$ and $\mathrm{Cd} / \mathrm{Ca}$ rations in recent benthic foraminifera under waters with spring-bloom activity should be compared with those values in regions where the spring bloom does not occur, in order to separate with more confidence the effects of high input of organic matter from the surface, and of lesser ventilation. Data from 
relative abundance on phytodetritus-free basis

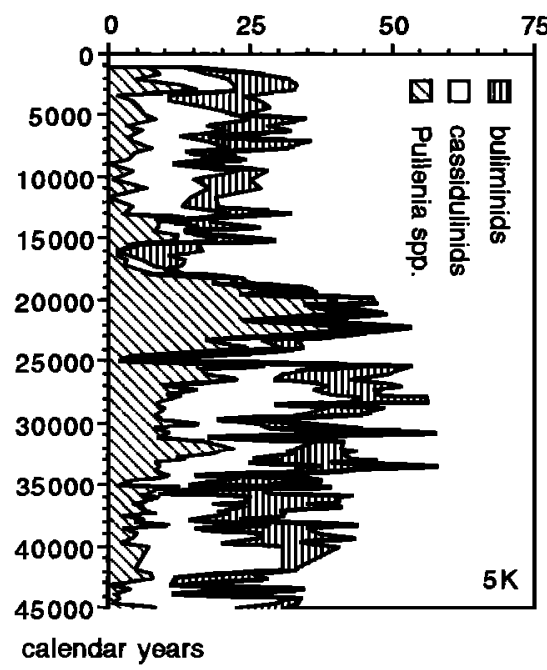

relative abundance, on phytodetritus-free basis

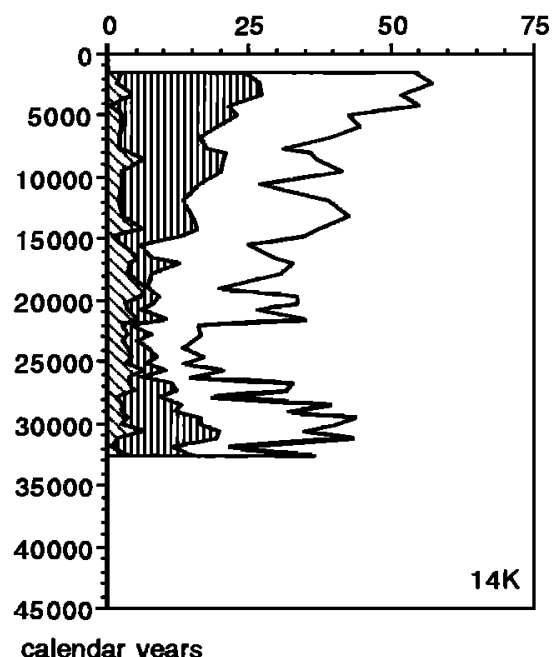

Figure 11. Relative abundance of low oxygen of high organic carbon or low oxygen species at 5K and 14K, plotted on a "phytodetritus species" - free basis.

the Southern Oceans clearly suggest that such effects may be of importance for reconstruction of deep water circulation [Mackensen et al, 1993a, b].

\section{Conclusions}

1. During the last 45,000 years major changes in benthic foraminiferal faunal composition, benthic foraminiferal accumulation rates and species richness at the location of cores $5 \mathrm{~K}$ and $14 \mathrm{~K}\left(50^{\circ}\right.$ and $\left.58^{\circ} \mathrm{N}\right)$ from the northeastem Atlantic were the result of changing abundances of $E$. exigua and $A$. weddellensis. In the present oceans these species are opportunists, and very abundant when a pronounced spring plankton bloom leads to seasonal deposition of phytodetritus to the seafloor. During glacial periods the abundance of these "phytodetritus species" was very low, and benthic foraminiferal diversity relatively high.

2. The strong decrease in absolute and relative abundance of these species during the last glacial maximum can be explained as evidence for strongly decreased surface water productivity at latitudes between $50^{\circ}$ and $58^{\circ} \mathrm{N}$ in the eastern Atlantic Ocean. High oceanic primary productivity during glacial periods thus must have occurred at lower latitudes.

3. Benthic foraminiferal faunas followed the migration of the polar front during glaciation-deglaciation, and productivity effects strongly overshadowed possible effects that changing rates of ventilation of the deep waters in the northeastern Atlantic may have had. Relative abundance of "low-oxygen" or "high organic carbon" infaunal species determined on a phytodetritus-species free basis suggests that decreased ventilation at the location of $5 \mathrm{~K}$, but not at the location of $14 \mathrm{~K}$, might have occurred during the last glacial maximum, but the evidence is weak.

4. Productivity was strongly reduced during Heinrich events, and less so during the Younger Dryas.

5. Comparison of benthic faunas, $\mathrm{Cd} / \mathrm{Ca}$ ratios in their tests and in the surrounding waters, and $\delta^{13} \mathrm{C}$ in tests and waters should be made between regions under strong spring bloom activity and in low-productivity regions, to estimate with confidence which parts of the observed signals in these proxy parameters is due to changes in spring bloom activity, which part is due to changes in ventilation.

Aclonowledgments. The authors acknowledge funding to N. J. Shackleton, EEC Grant EPOC 90.004; coring operations were funded by NERC-BOFS funds. We thank C. Bertram, A. Gooday, and H. Elderfield for discussions, and A. Altenbech, B. Corliss, A. Gooday, M. Katz, and J. Murray for reviews of this paper, which improved greatly thanks to their helpful suggestions. This is Cambridge Department of Earth Sciences contribution 3099, BOFS publication 297.

\section{References}

Alley, R. B., and D. R. MacAyeal, Ice-rafted detritus associated with binge-purge oscillations of the Laurentide Ice Sheet, Paleoceanography, 9, 503-512, 1994.

Altenbach, A. V., Short term processes and patterns in the foraminiferal response to organic flux rates, Mar: Micropaleontol., 19, 119-129, 1992.

Altenbach, A. V., and M. Sarnthein, Productivity record in benthic foraminifera, in Productivity of the Oceans: Present and Past, edited by W. H. Berger, V. S. Smetaceck, and G. Wefer, pp. 255-269, Springer-Verlag, New York, 1989.

Andrews, J. T., and K. Tedesco, Detrital carbonate rich sediments, northwestern Labrador Sea: Implications for ice sheet dynamics and iceberg rafting (Heinrich Events), Geology, 20, 1087-1090, 1992.

Balsam, W., Late Quaternary sedimentation in the western North Atlantic: Stratigraphy and paleoceanography, Palaeogeogr., PalaeoclimatoL, Palaeoecol., 35, 215-240, 1981.

Belanger, P. E., and S. S. Streeter, Distribution and ecology of benthic foraminifera in the Norwegian-Greenland Sea, Mar. Micropaleontol., 5, 401-428, 1980.

Berger, W. H., J. C. Herguera, C. B. Lange, and R. Schneider, Paleoproductivity: Flux proxies versus nutrient proxies and other problems concerning the Quaternary productivity record, in Carbon Cycling in the Glacial Ocean: Constraints on the Ocean's role in 
Global Change, edited by R. Zahn, T. F. Pedersen, M. A. Kaminski, and L. Labeyrie, pp. 385-411, Springer-Verlag, New York, 1994.

Berger, W. H., and G. Wefer, Productivity of the Oceans: Discussion of the iron hypothesis. Limnol. Oceanogr., 36, 1899-1918, 1991.

Bertram, C., H. Elderfield, J. MacDonald, and N. J. Shackleton, Cadmium/Calcium and carbon isotope reconstructions of the glacial northeast Atlantic Ocean. Paleoceanography, this issue.

Beveridge, N. A. S., H. Elderfield, and N. J. Shackleton, Deep thermohaline circulation in the low-latitude Atlantic during the last glacial. Paleoceanography, this issue.

Birchfield, G. E., and W. H. Broecker, A salt oscillator in the glacial Atlantic? a. A scale analysis model, Paleoceanography, 5, 835-846, 1990.

Boltovskoy, E., D. B. Scott, and F. S. Medioli, Morphological variations of benthic foraminiferal tests in response to changes in ecological parameters: A review, J. Paleontology, 65, 175-185, 1991.

Boltovskoy, E., S. Watanabe, V. I. Totah, and J. Vera Ocampo, Cenozoic benthic bathyal foraminifers of DSDP Site 548 (North Atlantic), Micropaleontology, 38, 183-207, 199.

Bond, G., et al., Evidence for massive discharges of icebergs into the North Atlantic Ocean during the last glacial period, Nature, 360, 245$249,1992$.

Boyle, E. A., Paired carbon isotope and cadmium data from benthic foraminifera: Implications for changes in oceanic phosphorus, oceanic circulation and atmospheric carbon dioxide, Geochim. Cosmochim. Acta, 50, 265-276, 1986.

Boyle, E. A., Cadmium and $\delta^{13} \mathrm{C}$ paleochemical ocean distributions during the stage 2 glacial maximum, Ann. Rev. Earth Planet. Sci., 2O, 245-287, 1992.

Boyle, E. A., and P. Rosener, Further evidence for a link between Late Pleistocene North Atlantic surface temperatures and North Atlantic Deep-Water production, Palaeogeogr., Palaeoclimatol, Palaeoecol., $89,113-124,1990$.

Broecker, W. S., The salinity contrast between the Allantic and Pacific Oceans during glacial time, Paleoceanography, 4, 201-212, 1986.

Broecker, W. S., and G. Denton, The role of ocean-atmosphere reorganizations in glacial cycles, Geochim. Cosmochim. Acta, 53, 2465-2501, 1989.

Broecker, W. S., M. Andree, W. Wolffli, H. Oescher, G. Bonani, J. Kennett, and D. Peteet, The chronology of the last deglaciation: Implications to the cause of the Younger Dryas Event, Paleoceanography, 3, 1-20, 1988.

Broecker, W. S., J. P. Kennett, B. P. Flower, J. T. Teller, S. Trumbore, G. Bonani and W. Wolftli, Routing of meltwater from the Laurentide ice sheet during the Younger Dryas cold episode, Nature, 341, 318$321,1989$.

Broecker, W. S., G. Bond, M. Klas, G. Bonani, and W. Wolfli, A salt oscillator in the North Atlantic? 1, The concept, Paleoceanography, $5,469-472,1990$.

Broecker, W. S., G. Bond, M. Klas, E. Clark, and J. McManus, Origin of the Northern Atlantic's "Heinrich Events", Clim. Dyn., 6, 265-273, 1992.

Burke, S. K., W. H. Berger, W. T. Coulbourn, and E. Vincent, Benthic foraminifera in Box Core ERDC 112, Ontong Java Plateau, J. Foram. Res., 23, 19-39, 1993.

Buzas, M. A., S. J. Culver, and Jorissen, F. J., A statistical evaluation of the microhabitats of living (stained) infaunal benthic foraminifera, Mar. Micropaleontol, 20,311-320, 1993.

Caralp, M. H., Impact de la matiere organique dans les zones de forte productivite sur certains foraminiferes benthiques, Oceanol. Acta ,7, 509-515, 1984.

Caralp, M. H., Deep-sea circulation in the northeastern Atlantic over the past 30,000 years: The benthic foraminiferal record. Oceanol. Acta, 10,27-40, 1987.

Caralp, M. H., Late Glacial to Recent deep-sea benthic Foraminifera from the Northeastern Atlantic (Cadiz Gulf) and Western
Mediterranean (Alboran Sea): Paleoceanographic results, Mar. Micropaleontol., 13, 265-289, 1988.

Caralp, M. H., Abundance of Bulimina exilis and Melonis barleeanum: Relationship to the quality of marine organic matter, Geo-Mar. Lett., 9, 37-43, 1989.

Charles, C. D., P. N. Froelich, M. A. Zibello, R. A. Mortlock, and J. J. Morley, Biogenic opal in Southern Ocean sediments over the last 450,000 years: Implications for surface water chemistry and circulation, Paleoceanography, 6, 697-728, 1991.

Corliss, B. H., Microhabitats of benthic foraminifera within deep-sea sediments, Nature, 314, 435-438, 1985.

Corliss, B. H., Morphology and microhabitat preferences of benthic foraminifera from the northwest Atlantic Ocean. Mar. Micropaleontol, 17, 195-236, 1991.

Corliss, B. H., and C. Chen, Morphotype patterns of Norwegian deepsea benthic foraminifera and ecological implications, Geology, 16, 716-719, 1988.

Corliss, B. H., and S. Emerson, Distribution of Rose Bengal stained deep-sea benthic foraminifera from the Nova Scotian continental margin and Gulf of Maine, Deep Sea Res., 37, 381-400, 1990.

Corliss, B. H., D. G. Martinson, and T. Keffer, Late Quaternary deepocean circulation, Bull. Geol. Soc. Am., 97, 1106-1121, 1986.

Cumy, W. B., J.-C. Duplessy, L Labeyrie, and N. J. Shackleton, Changes In the distribution of $\delta^{13} \mathrm{C}$ of deep water $\mathrm{\Sigma CO}_{2}$ between the last glaciation and the Holocene, Paleoceanography, 3, 317-341, 1988.

Douglas, R. G., and F. Woodruff, Deep sea benthic foraminifera, in The Sea, vol. 7, The Oceanic Lithosphere, edited by C. Emiliani, pp. 12331327, John Wiley, New York, 1981.

Duplessy, J.-C., N. J. Shackleton, R. G. Fairbanks, L. Labeyrie, D. Oppo, and N. Kallel, Deep water source variations during the last climatic cycle and their impact on the global deep water circulation, Paleoceanography, 3, 343-360, 1988.

Duplessy, J.-C., E. Bard, M. Arnold, N. J. Shackleton, J., Duprat, and L. Labeyrie, How fast did the ocean-atmosphere system run during the last deglaciation? Earth Planet. Sci. Lett., 103, 27-40, 1991.

Duplessy, J.-C., E. Bard, L. Labeyrie, J. Duprat, and J. Moyes, Oxygen isotope records and salinity changes in the Northeastern Atlantic Ocean during the last 18,000 years, Paleoceanography, 8, 341-350, 1993.

Fairbanks, R. G., C. D. Charles, and J. D. Wright, Origin of global meltwater pulses, in Radiocarbon After Four Decades, edited by $\mathbf{R}$. E. Taylor, pp. 473-499, Springer-Verlag, New York, 1992.

Flower, B. P., and J. P. Kennett, The Younger Dryas episode in the Gulf of Mexico, Paleoceanography, 5, 949-962, 1990.

François, R., M. P. Bacon, and M. A. Altabet, Glacial/interglacial changes in sediment rain rate in the SW Indian sector of Subantarctic waters as recorded by ${ }^{230} \mathrm{Th},{ }^{231} \mathrm{~Pa}, \mathrm{U}$ and $\delta^{15} \mathrm{~N}$, Paleoceanography, 8, 611-629, 1993.

Gage, J. D., and P. A. Tyler, Deep-Sea Biology, 504 pp. , Cambridge University Press, New York, 1991.

Gooday, A. J., A response by benthic foraminifera to the deposition of phytodetritus in the deep sea, Nature, 332, 70-73, 1988.

Gooday, A. J., Deep-sea benthic foraminiferal species which exploit phytodetritus: Characteristic features and controls on distribution, Mar. Micropaleontol., 22, 187-206, 1993.

Gooday, A. J., The biology of deep-sea foraminifera: A review of some advances and their applications in paleoceanography, Palaios, 9, 14$31,1994$.

Gooday, A. J., and P. J. D. Lambshead, Influence of seasonally deposited phytodetritus on benthic foraminiferal populations in the bathyal northeast Atlantic: The species response. Mar. Ecol. Progress Ser., 58, 53-67, 1989.

Gooday, A. J., L. A. Levin, P. Linke, and T. Heeger, The role of benthic foraminifera in deep-sea food webs and carbon cycling, in Deep-sea Food Chains and the Global Carbon Cycle, edited by G. T. Rowe and V. Pariente, pp. 63-91, Kluwer Academic, Norwell, Mass., 1992. 
Gooday, A. J., and C. M. Turley, Responses by benthic organisms to inputs of organic material to the ocean floor: A review, Philos. Trans $R$ Soc. London Ser. A, 331, 119-138, 1990.

Grousset, F. E., J. A. Sinko, M. Cremer, G. Bond, J. Duprat, E. Cortijo, and S. Huon, Patterns of ice-rafted detritus in the glacial North Atlantic (40-55 $\left.{ }^{\circ} \mathrm{N}\right)$, Paleoceanography, 8, 175-192, 1993.

Hallock, P., Fluctuations in the trophic resource continuum: a factor in global diversity cycles? Paleoceanography, 2, 457-471, 1987.

Heinrich, H., Origin and consequences of cyclic ice-rafting in the Northeast Atlantic Ocean during the past 130,000 years, Quat. Res., 29, 143-152, 1988.

Heinze, C., E. Maier-Reimer, and $\mathrm{K}$. Winn, Glacial $\mathrm{pCO}_{2}$ reduction by the world ocean: Experiments with the Hamburg carbon cycle model, Paleoceanography, 6, 395-430, 1991.

Herguera, J. C., Deep-sea benthic foraminifera and biogenic opal: Glacial to postglacial productivity changes in the western equatorial Pacific, Mar. Micropaleontol., 19, 79-98, 1992.

Herguera, J. C., Nutrient, mixing and export indices: A $250 \mathrm{kyr}$ productivity record from the western equatorial Pacific, in Carbon Cycling in the Glacial Ocean: Constraints on the Ocean's role in Global Change, edited by R. Zahn, T. F. Pedersen, M. A. Kaminski, and L. Labeyrie, pp. 481-520, Springer-Verlag, New York, 1994.

Herguera, J. C., and W. H. Berger, Paleoproductivity from benthic foraminifera abundance: Glacial to postglacial change in the westequatorial Pacific, Geology, 19, 1173-1176, 1991.

Herguera, J. C., E. Jansen, and W. H. Berger, Evidence for a bathyal front at $2000 \mathrm{~m}$ depth in the glacial Pacific, based on a depth transect on Ontong Java Plateau, Paleoceanography, 7, 273-288, 1992.

Hermelin, J. O. R., Variations in the benthic foraminiferal fauna of the Arabian Sea: a response to changes in upwelling intensity? Geol. Soc. London Spec. Publ, 64, 151-166, 1992.

Hermelin, J. O. R., and G. B. Shimmield, The importance of the oxygen minimum zone and sediment geochemistry in the distribution of Recent benthic foraminifera in the Northwest Indian Ocean, Mar. Geol, 91, 1-29, 1990.

Imbrie, J., et al., 1992, On the structure and origin of major glaciation cycles. 1. Linear responses to Milankovitch forcing, Paleoceanography, 7, 701-738, 1992.

Jasper, J. P., E. L. Sikes, A. C. Mix, F. G. Prahl, L. D. Keigwin, and J. M. Hayes, Molecular isotopic evidence of deglacial decline in $\mathrm{CO}_{2(\mathrm{aq})}$ concentration in the North Atlantic and control of late Quaternary atmospheric $\mathbf{p C O}_{2}$, paper presented at SEPM Meeting, Penn State Univ., University Park, Pa, Aug., 1993.

Jorissen, F. J., Benthic foraminifera from the Adriatic Sea: The relation with the organic flux. Utrecht Micropal. Bull., 37, 176 pp., 1988.

Jorissen, F. J., D. M. Barmawidjaja, S. Puskaric, and G. J. van der Zwaan, Vertical distribution of benthic foraminifera in the northern Adriatic Sea: The relation with the organic flux. Mar. Micropaleontol., 19, 131-146, 1992.

Kaiho, K., Benthic foraminiferal dissolved oxygen index and dissolved oxygen levels in the modern ocean, Geology, 22, 719-722, 1994.

Kennett, J. P., The Younger Dryas Cooling Event: An introduction, Paleoceanography, 5, 891-895, 1990.

Kipp, N. G., New transfer function for estimating past sea-surface conditions from sea-bed distribution of planktonic foraminiferal assemblages in the North Atlantic, Geol. Soc. Am. Mem., 145, 3-42, 1976.

Kumar, N., R. Gwiazda, R. F. Anderson, and P. N. Froelich, ${ }^{231} \mathrm{~Pa} /{ }^{230} \mathrm{Th}$ ratios in sediments as a proxy for past changes in Southern Ocean productivity, Nature, 362, 45-48, 1993.

Labeyrie, L. D., J.-C. Duplessy, J. Duprat, A. Juillet-Leclerc, J. Moyes, E. Michel, N. Kallel, and N. J. Shackleton, Changes in the vertical structure of the North Atlantic Ocean between glacial and modern times, Quat. Sci. Rev., 11, 401-413, 1992.

Lagoe, M. B., Recent benthic foraminifera from the central Arctic Ocean, J. Foram. Res., 7, 106-129, 1977.
Lagoe, M. B., Recent benthonic foraminiferal biofacies in the Arctic Ocean, Micropaleontol., 25, 214-224, 1979.

Lambshead, P. J. D., and A. J. Gooday, The impact of seasonally deposited phytodetritus on epifaunal and shallow infaunal benthic foraminiferal populations in the bathyal northeast Atlantic: The assemblage response, Deep Sea Res., 37, 1263-1283, 1990.

Lehman, S. J., and L. D. Keigwin, Sudden changes in North Atlantic circulation during the last deglaciation, Nature, 356, 757-762, 1992.

Linke, P., and G. F. Lutze, Microhabitat preferences of benthic foraminifera: A static concept or a dynamic adaptation to optimize food acquisition? Mar. Micropaleontol, 20, 215-233, 1993.

Lochte, K., and C. M. Turley, Bacteria and phytodetritus associated with phytodetritus in the deep sea, Nature, 333, 67-69, 1988.

Lohmann, G. P., Abyssal benthonic foraminifera as hydrographic indicators in the western South Atlantic Ocean, J. Foram. Res., 8, 634, 1978.

Loubere, P., Deep-sea foraminiferal assemblage response to a surface ocean productivity gradient: A test, Paleoceanography, 6, 193-204, 1991.

Lutze, G. H., Distribution of benthic foraminifera on the continental margin off NW Africa, "Meteor" Forschungsergebn., C32, 31-80, 1981.

Lutze, G. H., and W. T. Coulbourn, Recent benthic foraminifera from the continental margin off northwest Africa: Community structure and distribution, Mar. Micropaleontol., 8, 361-401, 1984.

Mackensen, A., D. K. Fuetterer, H. Grobe, and G. Schmiedl, Benthic foraminiferal assemblages from the eastern Southern Atlantic Polar front region between $35^{\circ}$ and $75^{\circ} \mathrm{S}$ : Distribution, ecology and fossilization potential. Mar. Micropaleontol., 22, 33-69, 1993a.

Mackensen, A., H. Grobe, H.-W. Hubberten, and G. Kuhn, Benthic foraminiferal assemblages and the $\delta^{13} \mathrm{C}$ signal in the Atlantic sector of the Southern Ocean: Glacial to interglacial contrasts, in Carbon Cycling in the Glacial Ocean: Constraints on the Ocean's role in Global Change, edited by R. Zahn, T. F. Pedersen, M. A. Kaminski, and L. Labeyrie, L., pp. 87-103, Springer-Verlag, New York, 1994.

Mackensen, A., H.-W. Hubberten, T. Bickert, G. Fischer, and D. K. Fuetterer, The $\delta^{13} \mathrm{C}$ in benthic foraminiferal tests of Fontbotia wuellerstorf (Schwager) relative to the $\delta^{13} \mathrm{C}$ of dissolved inorganic carbon in the Southern Ocean deep water: Implications for glacial ocean circulation models, Paleoceanography, 8, 587-610, $1993 \mathrm{~b}$.

Mackensen, A., H.-P. Sejrup, and E. Jansen, The distribution of living benthic foraminifera on the continental slope and rise off southwest Norway, Mar. Micropaleont., 9, 275-306, 1985.

Manighetti, B., and I. N. McCave, Depositional fluxes, paleoproductivity, and ice rafting in the norheast Atlantic over the last $30 \mathrm{ka}$, Paleoceanography, this issue, a.

Manighetti, B., and I. N. McCave, Late glacial and Holocene paleocurrents around South Rockall Bank, northeastern Atlantic, Paleoceanography, this issue, $b$.

Manighetti, B., M. A. Maslin, I. N. McCave, and N. J. Shackleton, Chronology for climatic change: Developing age models for the Biogeochemical Ocean Flux Study cores, Paleoceanography, this issue.

Maslin, M. A., A study of the Palaeoceanography of the N. E. Atlantic in the late Pleistocene, Ph.D. thesis, pp. 1-640, Univ. Cambridge, Cambridge, England, 1993.

Maslin, M. A., N. J. Shackleton, and U. Pflaumann, Surface water temperature, salinity and density changes of the surface waters of the northeastern Atlantic during the last 45,000 years: Heinrich events, deep water formation and climatic rebounds, Paleoceanography, this issue.

MoClain, C. R., G. Feldman, and W. Esaias, Oceanic biological productivity, in Atlas of Satellite Observations Related to Global Change, edited by R. J. Gurney, J. L. Foster, and C. L. Parkinson, pp. 251-263, Cambridge University Press, New York, 1993.

McCorkle, D. C., L. D. Keigwin, B. H. Corliss and S. R. Emerson, The 
influence of microhabitats on the carbon isotope composition of deep-sea benthic foraminifera, Paleoceanography, 5, 161-185, 1990.

McIntyre, A., N. G. Kipp, A. W. H. Be, T. Crowley, T. Kellogg, J. V. Gardner, W. Prell, and W. F. Ruddiman, Glacial North Atlantic 18,000 years ago: A CLIMAP reconstruction. Mem. Geol Soc. Am. 145, 43-76, 1976.

Miao, Q., and R. C. Thunell, Recent deep-sea benthic foraminiferal distributions in the South China and Sulu Seas, Mar. MicropaleontoL, 22, 1-32, 1993.

Miller, K. G., and G. P. Lohmann, Environmental distribution of Recent benthic foraminifera on the northeast United States continental slope. Bull. Geol. Soc. America, 93, 200-206, 1982.

Mix, A. C., and R. G. Fairbanks, North Atlantic surface ocean control of Pleistocene deep-water circulation, Earth Planet. Sci. Lett,, 73, 231243, 1985.

Mortlock, R. M., C. D. Charles, P. N. Froelich, M. Zibello, J. Saltzman, L. D. Burckle, and J. D. Hays, Evidence for lower productivity in the Antarctic Ocean during the last glaciation, Nature, 351, 220-222, 1991.

Murray, J. W., J. F. Weston, C. A. Haddon, and A. D. J. Powell, Miocene to Recent bottom water masses of the northeast Allantic: An analysis of benthic foraminifera, Geol. Soc. London Spec. Publ., 21, 219-230, 1986

Murray, R. W., M. Leinen and A. R. Isern, The biogenic flux of Al to sediment in the equatorial Pacific Ocean: Evidence for increased productivity during glacial periods, Paleoceanography, 6, 651-669, 1993.

Nelson, C. S., P. J. Cooke, C. H. Hendy, and A. M. Cuthberson, Oceanographic and climatic changes over the past 160,000 years at Deep-Sea Drilling Project Site 594 off southeastern New Zealand, southwest Pacific Ocean, Paleoceanography, 8, 435-458, 1993.

Oppo, D. W., and S. J. Lehman, Mid-Depth circulation of the subpolar North Atlantic during the last glacial maximum, Science, 259, 1148$1152,1993$.

Pedersen, T. F., Increased productivity in the eastern equatorial Pacific during the last glacial maximum $(19,000$ to 14,000 year BP.), Geology, 11, 16-19, 1983.

Pedersen, T. F., M. Pickering, J. S. Vogel, J. N. Southon and D. E. Nelson, The response of benthic foraminifera to productivity cycles in the eastern equatorial Pacific: Faunal and geochemical consiraints on glacial bottom water oxygen levels, Paleoceanography, 3, 157$168,1988$.

Rathburn, A. E., and B. H. Corliss, The ecology of living (stained) benthic foraminifera from the Sulu Sea, Paleoceanography, 9, 87$150,1994$.

Rosoff, D. B., and B. H. Corliss, An analysis of Recent deep-sea benthic foraminiferal morphotypes from the Norwegian and Greenland Seas, Palaeogeogr., Palaeoclimatol, Palaeoecol, 91, 13-20, 1992.

Rowe, G. T., Biomass and production of the deep-sea macrobenthos, in Deep-sea Biology, vol. 8, The Sea, edited by G. T. Rowe, pp. 97-121, John Wiley, New York, 1983.

Ruddiman, W. F., Late Quaternary deposition of ice-rafted sand in the subpolar North Atlantic (lat. $40^{\circ}$ to $65^{\circ} \mathrm{N}$ ). Bull Geol. Soc. Am., 88, 1813-1827, 1977.

Ruddiman, W. F., and A. McIntyre, The North Atlantic Ocean during the last deglaciation, Palaeogeogr., Palaeoclimatoh, Palaeoecol, 35, $145-214,1985$.

Sancetta, C. , Primary production in the glacial North Atlantic and North Pacific Oceans, Nature, 360, 249-250, 1992.

Sanders, H. L., Marine benthic diversity: A comparative study, Am. Nat., 102, 243-282, 1968.

Sarnthein, M., K. Winn, J.-C. Duplessy, and M. Fontugne, Global variations of surface ocean productivity in low and mid latitudes: Influence on $\mathrm{CO}_{2}$ reservoirs of the deep ocean and atmosphere during the last 21,000 years, Paleoceanography, 3, 361-399, 1988.

Schnitker, D., West Atlantic abyssal circulation during the past 120,000 years, Nature, 248, 385-387, 1974.
Schnitker, D., The deep waters of the western North Atlantic during the past 24,000 years, and reinitiation of the Western Boundary Undercurrent, Mar. Micropaleontol., 4, 265-280, 1979.

Schnitker, D., Quaternary deep-sea benthic foraminifera and bottom water masses, Ann. Rev. Earth Planet. Sci., 8, 343-370, 1980.

Schnitker, D., High resolution records of benthic foraminifers in the late Neogene of the northeastern Atlantic Ocean. Initial Rep. Deep Sea Drill. Project, 81, 611-622, 1984.

Schnitker, D., Deep-sea benthic foraminifers: Food and bottom water masses, in Carbon Cycling in the Glacial Ocean: Constraints on the Ocean's role in Global Change, edited by R. Zahn, T. F. Pedersen, M. A. Kaminski and L. Labeyrie, pp. 539-554, Springer-Verlag, New York, 1994.

Schroeder, C. J., D. B. Scott and F. S. Medioli, Can smaller benthic foraminifera be ignored in paleoenvironmental analyses? J. Foram. Res., 17, 101-105, 1987.

Scott, D. B., and G. Vilks, Benthonic foraminifera in the surface sediments of the deep-sea Arctic Ocean, J. Foram. Res., 21, 20-38, 1991.

Seidenkrantz, M.-S., Benthic foraminiferal and stable isotopic evidence for a "Younger Dryas-style" cold spell at the Saalian-Eemian transition, Denmark. Palaeogeogr., Palaeoclimatol., Palaeoecol, 102, 103-120, 1993.

Sejrup, H.-P., T. Fjaeren, M. Hald, L. Beck, J. Hagen, I. Miljeteig, I. Morvik and O. Norvik, Benthonic foraminifera in surface samples from the Norwegian continental margin between $62^{\circ} \mathrm{N}$ and $65^{\circ} \mathrm{N}, J$. Foram. Res., 11, 277-295, 1981.

Sen Gupta, B. K., and M. L. Machain-Castillo, Benthic foraminifera in oxygen-poor habitats. Mar. Micropaleontol, 20, 183-201, 1993.

Shemesh, A., S. A. Macko, C. D. Charles and G. H. Rau, Isotopic evidence for reduced productivity in the glacial Southern Ocean, Science, 262, 407-410, 1993.

Sjoerdsma, P. G., and G. J. van der Zwaan, Simulating the effect of changing organic flux and oxygen content on the distribution of benthic foraminifera, Mar. Micropaleontol, 19, 163-180, 1992.

Smart, C., S. C. King, A. Gooday, J. W. Murray and E. Thomas, A benthic foraminiferal proxy of pulsed organic matter paleofluxes, Mar. Micropaleontol., 23, 89-100, 1994.

Streeter, S. S.,. Bottom water and benthonic foraminifera in the North Atlantic: Glacial-interglacial contrasts, Quat. Res., 3, 131-141, 1973.

Streeter, S. S., and S. A. Lavery, Holocene and latest glacial benthic foraminifera from the slope and rise off eastern North America, Bull Geol. Soc. Am, 93, 190-199, 1982.

Streeter, S. S., and N. J. Shackleton, Paleocirculation of the deep North Atlantic: 150,000 year record of benthic foraminifera and oxygen18. Science, 203, 168-171, 1979.

Thiel, H., et al., Phytodetritus on the deep-sea floor in a Central Oceanic Region of the Northeast Atlantic, Biol. Oceanogr., 6, 203-239, 1988/1989.

Thomas, E., Late Eocene to Recent deep-sea benthic foraminifers from the central equatorial Pacific Ocean, Initial Rep. Deep Sea Drill. Project, 85, 655-679, 1985.

Thomas, E., Changes in composition of Neogene benthic foraminiferal faunas in equatorial Pacific and north Atlantic. Palaeogeogr., Palaeoclimatol., Palaeoecol., 53, 47-61, 1986a.

Thomas, E., Early to middle Miocene benthic foraminiferal faunas from DSDP Sites 608 and 610, North Atlantic, Geol. Soc. London Spec. Publ., 21, 205-218, 1986b.

Thomas, E., and E. Vincent, Major changes in benthic foraminifera in the equatorial Pacific before the middle Miocene polar cooling, Geology, 15, 1035-1039, 1987.

Thomas, E., and E. Vincent, Early to middle Miocene deep-sea benthic foraminifera in the equatorial Pacific, Revue de Paleobiologie, Spec. VoL, 2 (BENTHOS '86), 583-588, 1988.

Turley, C. M., A. Gooday and J. C. Green, Maintenance of abyssal benthic foraminifera under high pressure and low temperature: Some preliminary results, Deep Sea Res., 40A, 643-652, 1993. 
Turley, C. M., and K. Lochte, Microbial response to the input of fresh detritus to the deep-sea bed, Palaeogeogr., Palaeoclimatol., Palaeoecol, 89, 3-23, 1990.

Van der Zwaan, G. J., Paleoecology of late Miocene Mediterranean Foraminifera, Utrecht Micrapaleont. Bull., 25, 5-193, 1982.

Van der Zwaan, G. J., and F. J. Jorissen, Biofacial patterns in riverinduced shelf anoxia, Geol. Soc. London Spec. Publ., 58, 65-82, 1991.

van Weering, T. C. E. and S. de Rijk, Sedimentation and climateinduced sediments on Feni Ridge, Northeast Atlantic Ocean, Mar. Geol., 101, 49-69, 1991.

Vergnaud-Grazzini, $\mathbf{C}$., and C. Pierre, The carbon isotope distribution in the deep $\mathrm{\Sigma CO}_{2}$ and benthic foraminifers of the Alboran basin, western Mediterranean: implications for variations in primary production levels since the last deglaciation, Mar. MicropaleontoL, 19, 147-161, 1992.

Veum, T., E. Jansen, M. Arnold, I. Beyer and J.-C. Duplessy, Water mass exchange between the North Atlantic and the Norwegian Sea during the past 28,000 years, Nature, 356, 783-785, 1992.

Yoder, J. A., C. R. McClain and G. C. Feldman, Annual cycles of phytoplankton chlorophyll concentrations in the global ocean: A satellite view. Global Biogeochem. Cycles, 7, 181-193, 1993.

L. Booth and N. J. Shackleton, Godwin Laboratory, Subdepartment of Quaternary Research, University of Cambridge, Cambridge CB2 3RS, England.

M. Maslin, Geologisch - Palaeontologisch Institut und Museum der Universitaet Kiel, Olshaussenstrasse 40-80, D-24118 Kiel, Germany.

E. Thomas, Center for the Study of Global Change, Department of Geology and Geophysics, Yale University, P. O. Box 208109, New Haven, CT 06520-2108. (e-mail: ethomas@eagle.wesleyan.edu)

(Received Decmber 15, 1993; revised September 30, 1994; accepted November 18, 1994.) 